\title{
THE POSSIBILITY OF IMPROVING SURFACE IRRIGATION WITH BLOCKED END ON SPARSE GRAPE TREES
}

\author{
Kamal H. H. Amer \\ ABSTRACT
}

Border system that applies water over the whole soil surface is a widely used method of surface irrigation in Egypt to irrigate grape farms. Furrow system can be used to lessen water applied per irrigation in distant parallel channels to partially wet the soil surface along with plants line. A field study was carried out in northern Egypt to authorize using distant furrows rather than borders as an improving irrigation system for grape farms on a clay loam soil with $1.3 \mathrm{~g} \mathrm{~cm}^{-3}$ bulk density during 2008 season in Shibin El-Kom area, Egypt. Border irrigation was practiced to apply 9.8, 12.0, and $15.5 \mathrm{~m}^{2} / \mathrm{h}$ inflow rate per unit width when gravimetric soil moisture content was initialized at 24.7\%. A 9.8 $\mathrm{m}^{2} / \mathrm{h}$ per unit width was applied when soil moisture content by weight was initialized as 21.4, 24.7, and 27.1\%. Inflow rates of 2.2, 3.0, $4.0 \mathrm{~m}^{3} / \mathrm{h}$ were applied by furrow irrigation at $25.1 \%$ initial moisture content by weight. Gravimetric initial moisture contents 22.7, 25.4, and 27.2\% were initialized under furrow irrigation with $2.2 \mathrm{~m}^{3} / \mathrm{h}$ inflow rate. The results showed that the greater inflow rate or the wetter initial soil surface was applied, the smaller water advance time and the greater recession time were occurred. Infiltrated water depth was individually increased by decreasing either inflow rate or initial soil moisture content. Coefficient of variation as well as distribution and application efficiencies was generally improved by increasing inflow rate, initial soil moisture content, or storage phase time. Water use per day was ranged from 4.9 to $6.1 \mathrm{~mm}$ by border irrigation and from 2.8 to $3.6 \mathrm{~mm}$ by partially wetted furrow irrigation. Water saving was achieved as 39.5-49\% by partially wetted furrow irrigation compared to border as practiced in grape farm. Grape yield was significantly improved with increasing inflow rate, initial moisture, and storage phase.

Keyword: surface irrigation; evaluation; water distribution and efficiency; water use.

Associate Professor, Agricultural Engineering Dept., Minofia University, Shibin El-Kom, 32511, Egypt 


\section{INTRODUCTION}

urface irrigation is the most widely used method of irrigation in Egypt. Surface irrigation is the application of a controlled stream of water to an inlet of the field and its subsequent gravity distribution over the field. Surface irrigation efficiency is generally low in comparison to sprinkler and trickle irrigation, but, it will remain popular in the Nile Delta as located in northern Egypt due to anticipated shortage of water and the high cost of energy. Surface irrigation is accomplished by one of several application methods including borders, furrows, checks and basins. In each case, water flows by gravity from one upstream of the field towards the downstream end over the land.

Border system is a surface irrigation method that applies water into the strip ridge and vertically beneath the border surface. The surface depths of water are essentially small in comparison to border width. The surface flow determines the length of time during which water enters the soils. The infiltrated time can be represented to Kostiakow's equation (Maheshwari et al., 1988; Hartley, 1992; Dholakia et al., 1998). Considering the dependent of infiltration time, water flow over land surface is spatially varied unsteady open channel flow.

In the furrow irrigation of surface irrigation, water is applied in a specific rate of flow into closely spaced parallel channels for intensive growing crop. These small channels convey the water across the slope of the field to the vicinity of plants growing along the furrow from the high end of the field to the low end. This method differs from any one of surface irrigation in that only part of ground surface is covered with water. The water infiltrates the soil both vertically and horizontally. The furrow stream applied until the desired application depth and lateral penetration is obtained. How long water can be applied in the furrows depends on the volume of water required to fill the soil to the desired depth, the intake rate of the soil, and the spacing of the furrow. New practice of furrow irrigation that developed to irrigate sparse fruit trees in this work is to apply water in a specific rate of flow into distantly spaced parallel channels in order to lessening water applied per irrigation.

In surface irrigation, it is always desirable to obtain high water distribution and application efficiency. It is also requisite for lengths of 
the irrigation runs to be as long as possible because of the high labor requirements for irrigating farms with short runs. The desirable goals of surface irrigation techniques depend on high water distribution and water savings will be achieved. The water losses are deep seepage and runoff, which can not be avoided. Because of this, the application efficiency of surface irrigation is sometimes low. The research work will deal with water loss by deep seepage because water loss by runoff is avoided by using surface irrigation with blocked end.

Irrigation water is generally infiltrated into rootzone during conveyance and recession of water at the soil surface. The inlet stream size should be adjusted to meet the intake characteristics of the soil, the slope, and the entire area to provide a nearly uniform time for water to be infiltrated at all points along the length of the furrow, border, or basin. Three phenomena should be considered in surface irrigation design: (1) the intake characteristics of the soil; (2) the rate of advance of water front moving along the furrow or strip; (3) the rate of recession of water along the furrow or strip after water has been cutoff (Fig. 1). The shape of water infiltrated with depth depends on numerous factors, such as the variability of the soil, flow channel shape, type of irrigation (furrow versus border strip), inflow rate, irrigation hydraulics, duration of the irrigation, and slope of the field (Vaziri and Wu, 1972; Holzapfel et al., 1984; Blair and Smerdon, 1988; Walker and Skogerboe, 1987; Valiantzas et al., 2000; Alazba, 1999). Irrigation efficiency can also be improved when water losses are lessened by optimum scheduling and design match.

Infiltration rate is the rate at which water enters the soil. A soil's infiltration rate will vary greatly according to its structure, tilth, density, porosity, and moisture content. The infiltration rate of a soil may impose a limitation upon the design of an irrigation system, since water application rates in excess of the infiltration rate may result in runoff and erosion. Green and Guernsey (1984) studied infiltration rate for different soil structures. They found field infiltration rates obtained with doublering infiltrometer are fitted to Kostiakov (1932) equation. The measured intake rates for individual infiltration runs were obtained at 2- to 10 minute intervals for the duplicate measurement locations at each of the three sites. They found cumulative infiltration curves by calculating sum 
of measured "rate $\times$ time" quantities. Intake rates during refilling of infiltration rings were assumed to be the mean of measured values before and after refilling. Hume (1993) predicted the infiltration parameters of three common equations (Kostiakov, modified Kostiakov, and Horton) accurately from measured field data on a clay soil using a regression approach. He found a high correlation among the infiltration parameters in fitting to the three equations with the field data and the parameters of the fitted equations were extremely sensitive to error in measuring field data.

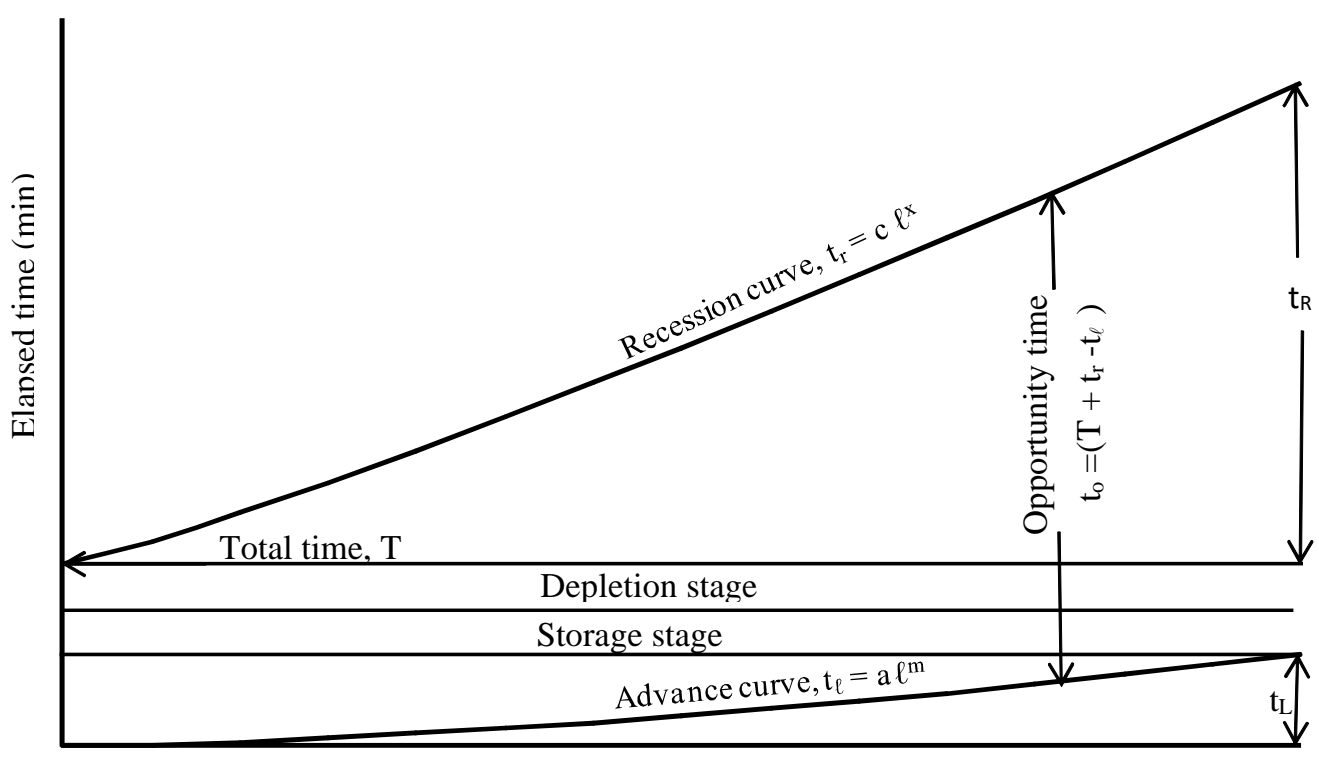

Irrigated field length, $\ell$ (m)

Fig. 1: Infiltrated water depth by surface irrigation using water advance and monocsion

The time interval during which infiltration of water into the soil can occur is bounded by the advance and recession functions (Fig. 1) and is defined as the infiltration opportunity time (Holzapfel et al., 1984; Foroud et al., 1996; Rodriguiz, 2003). Water flow, soil surface roughness, and infiltration rate affect the non-uniform and unsteady of flow pattern into root zone along furrow or border of surface irrigation. Water inflow is expressed in a continuity equation and an equation of motion (Michael and Pandya, 1971; Cahoon et al., 1995). Bishop (1962) and Wu (1971) studied individual inflow as water advance effects on water outflow. Their 
derivations of infiltrated water into soil along furrow were based on advance and storage stages of surface irrigation interrelation with soil infiltration rate.

Evaluation of surface irrigation based on measurements of advance and recession phase and an independent measurement of soil infiltration is affected by inlet flow, soil type, furrow slope, length, shape, time of cutoff irrigation and cultivated crop all of which are design parameters. Alternatively, the three preceding functions are responsible to shape infiltrated water distribution curve. Soil infiltration rate I is an empirical power function (Kostiakov, 1932; Smerdon et al., 1988; DeTar, 1989; Rodriguiz, 2003) describing the rate in $\mathrm{mm} / \mathrm{min}$ as a function of opportunity time in minute.

The purpose of the work is to manage surface irrigation system to be more efficient on irrigating grape farms. A goal of the work is to study the possibility of using partially wetted furrow instead of border to irrigate grape trees. A specific study is to evaluate and scheduling both irrigation systems based on changing inflow rate, initial soil moisture content, and storage phase time.

\section{MATERIALS AND METHODS}

A field experiment was conducted in an arid site in northern Egypt (Shibin El-Kom area, $17.9 \mathrm{~m}$ above sea level, $30^{\circ} 32^{\prime} \mathrm{N}, 31^{\circ} 03^{\prime} \mathrm{E}$ ) on grape trees which have 6 years old during 20 Feb.-2 Jul. 2008 growing season. Soil in the study area was classified as clay loam with $1.3 \mathrm{~g} \mathrm{~cm}^{-3}$ average soil bulk density for $1 \mathrm{~m}$ soil depth. Soil particle sizes for $1 \mathrm{~m}$ soil profile were distributed as shown in Table 1. The soil moisture content of one meter soil depth by weight as measured using pressure membrane was shown in Table 1. Irrigation water was applied into the field using two types of surface irrigation which were border and furrow irrigation systems. Three Inflow rates per unit width $(9.8,12.0$, and 15.5 $\mathrm{m}^{2} / \mathrm{h}$ ) were applied by border irrigation when gravimetric soil moisture content was initialized to $24.7 \%$. Three inflow rates $(2.2,3.0$, and 4.0 $\mathrm{m}^{3} / \mathrm{h}$ ) were flowed by furrow irrigation when initial soil water content was initialized to $25.1 \%$ by weight. A $9.8 \mathrm{~m}^{2} / \mathrm{h}$ inlet flow rate per unit width was applied by border system for three initial levels of gravimetric 
soil content $(21.4,24.7$, and $27.1 \%)$. A $2.2 \mathrm{~m}^{3} / \mathrm{h}$ inflow rate was applied by furrow system for three initial levels of soil moisture $(22.7,25.4$, and $27.2 \%$ ) by weight. To study the effect of water storage phase time on the distribution of water along border and furrow lines throughout the soil profile and on the efficiency, the same treatments were carried out based on increasing cutoff time from when water reached the field end from 0 to 5 and $10 \mathrm{~min}$ for border irrigation and from 0 to 10 and $20 \mathrm{~min}$ for furrow irrigation. All the preceding measurements were done based on the changes of water storage phase time. For that purpose, the field was divided into three plots; each plot represented a storage phase treatment. The plot size as shown in Fig. 2 was 60 by $60 \mathrm{~m}$ with $2.5-\mathrm{m}$ row width and 2-m spacing between trees. Each treatment in the same plot was replicated two times as shown in Fig. 2.

Table 1: Physical properties of different soil layers of the experimental field.

\begin{tabular}{|c|c|c|c|c|c|c|c|}
\hline \multirow{2}{*}{$\begin{array}{c}\text { Soil depth } \\
(\mathrm{cm})\end{array}$} & \multicolumn{2}{|c|}{ Particles Size distribution $(\%)$} & $\mathrm{PWP}^{*}$ & $\mathrm{FC}^{*}$ & $\mathrm{SP}^{*}$ & $\rho^{*}$ \\
\cline { 2 - 8 } & Sand & Silt & Clay & $\left(\mathrm{g} \mathrm{g}^{-1}\right)$ & $\left(\mathrm{g} \mathrm{g}^{-1}\right)$ & $\left(\mathrm{g} \mathrm{g}^{-1}\right)$ & $\left(\mathrm{g} \mathrm{cm}^{-3}\right)$ \\
\hline $0-20$ & 25.0 & 30.2 & 44.8 & 16.2 & 30.8 & 56.0 & 1.25 \\
\hline $20-40$ & 17.79 & 31.14 & 51.07 & 16.4 & 33.8 & 55.7 & 1.28 \\
\hline $40-60$ & 15.68 & 27.42 & 56.9 & 16.0 & 33.2 & 55.5 & 1.31 \\
\hline $60-80$ & 21.5 & 34.37 & 44.13 & 15.4 & 32.0 & 55.2 & 1.33 \\
\hline $80-100$ & 13.13 & 36.61 & 50.26 & 15.0 & 30.4 & 54.6 & 1.33 \\
\hline Average & 18.6 & 31.9 & 49.5 & 15.8 & 32.0 & 55.4 & 1.30 \\
\hline
\end{tabular}

*PWP, permanent wilting point; FC, field capacity; SP, saturation point; $\rho$, bulk density. Furrow and border with blocked ends were both $60 \mathrm{~m}$ in length. Border width was $2.5 \mathrm{~m}$ as equal to plant row spacing. It was $0.8 \mathrm{~m}$ in width for partially wetted furrow irrigation. Figure 3 showed the shape of the border and furrow profiles. The field slope was measured using 60-m water pipe along field and 2-m across the field width. The water head difference between pipe up-and-down stream ends was measured and divided by pipe length, the slope was found to be $0.12 \%$ along field length and zero for width. The ground water level was measured as 2.94 $\mathrm{m}$ in 2008 grape season. Water advance and recession time recorded each $5 \mathrm{~m}$ along border and furrow lengths for all treatments. Soil water content along border and furrow measured for $1 \mathrm{~m}$ soil depth in thirteen stations using soil sample in which taken by augur. The total flow time $\mathrm{T}$ which including the time of water advance, storage, and depletion was recorded 
from the time the water turned on to the moment of water disappeared at the upstream end. Water advance and recession times as a function of furrow length were recorded in empirical equations. Inflow rate was measured using flow meter each treatment. The significance deference was found by Duncan's method.

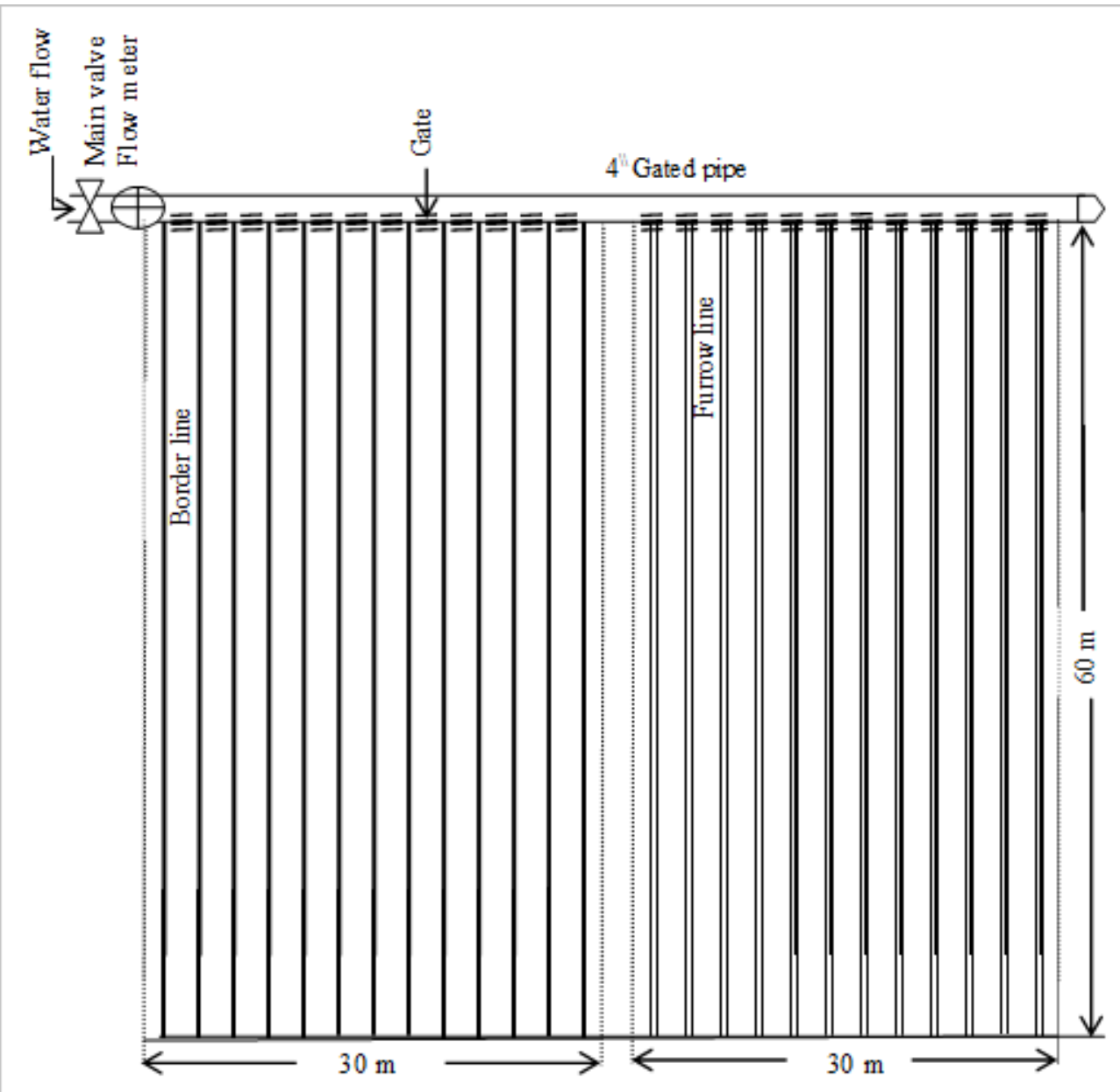

Fig. 2: Experimental layout for a storage phase treatment.

The determined infiltrated depth which was compared to the corresponding measured depth was found according to the following hydraulic theory as:

Infiltration rate was measured by infiltrometer and expressed in power equation as:

$\mathrm{I}=\mathrm{k} \mathrm{t}_{\mathrm{o}}^{\mathrm{n}-1} \quad----$ 
where $\mathrm{I}$ is infiltration rate in $\mathrm{mm} / \mathrm{min}, \mathrm{t}_{\mathrm{o}}$ is an intake opportunity time in minute, $\mathrm{k}$ and $\mathrm{n}$ are empirical coefficients.

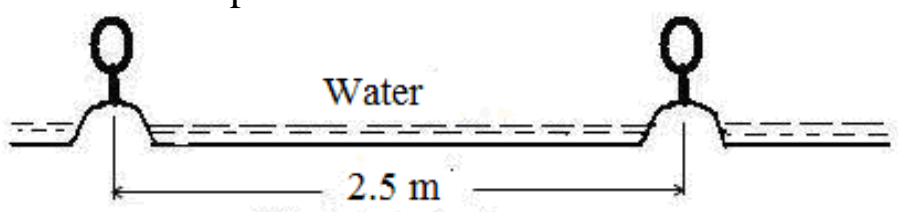

a) Border irrigation shape. Plant location

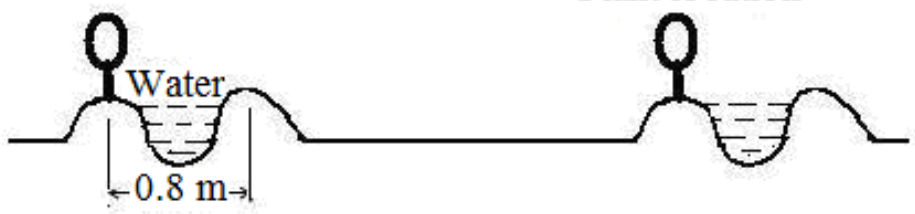

b) Partially wetted furrow irrigation shape.

Fig. 3: Border and furrow shapes as practiced in grape farm.

The cumulative infiltrated depth as a function of opportunity time was derived by integrating the right side of Eq. (1) respect to opportunity time and expressed as:

$$
\mathrm{Z}=\frac{\mathrm{k}}{\mathrm{n}} \mathrm{t}_{\mathrm{o}}^{\mathrm{n}} \quad----(2)
$$

where $\mathrm{Z}$ is infiltrated depth in $\mathrm{mm}$ and $\mathrm{n}$ is infiltration power coefficient which ranges from 0.8 to 0.2 for most soil types.

Water advance and recession functions were combined to define the infiltration opportunity time along furrow or strip length as shown previously in Fig. 1. The two functions were defined as advance or recession time versus distance $\ell$ along the furrow or strip and formulated in empirical power equations (Elliot and Walker, 1982; Walker and Skogerboe, 1987; Scaloppi et al., 1995; Rodriguiz, 2003) as follows:

$$
\begin{gathered}
\mathrm{t}_{\ell}=\mathrm{a} \ell^{\mathrm{m}} \\
\mathrm{t}_{\mathrm{r}}=\mathrm{c} \ell^{\mathrm{x}}
\end{gathered}
$$

where $t_{\ell}$ is advance time in min, $t_{r}$ is recession time in min, and $\ell$ is furrow or strip length in meter, and a, c, m, and $\mathrm{x}$ are empirical coefficients in the equations.

The water infiltration opportunity time along furrow or strip length which was the difference between the last time when water disappeared to the first time when water started at the same point along furrow or strip was determined as follows:

$$
\mathrm{t}_{\mathrm{o}}=\mathrm{T}+\mathrm{t}_{\mathrm{r}}-\mathrm{t}_{\ell}----
$$


where $t_{0}$ is intake opportunity time when water depth along furrow or strip totally infiltrated into the root zone in minute and $\mathrm{T}$ is total time of advance, storage, and depletion (duration time that started from water turn on and ended when the water at the upstream end disappeared) in minutes as shown in Fig. 1. When storage and depletion has not occurred, total time $\mathrm{T}$ is taken from water turn on to cutoff.

The infiltrated water depth $\mathrm{Z}$ along furrow was formulated according to Amer (2007) by incorporating Eqs. (3) and (4) into Eq. (5), subsequently applying Eq. (2) as follows:

$$
\mathrm{Z}=\frac{\mathrm{k}}{\mathrm{n}}\left(\mathrm{T}+\mathrm{c} \ell^{\mathrm{x}}-\mathrm{a} \ell^{\mathrm{m}}\right)^{\mathrm{n}}----(6)
$$

The average width of flow in the border was taken $2.5 \mathrm{~m}$ as equal to the strip width. But the average width of flow in the distant parallel furrows (w) was determined as follows:

$$
\mathrm{w}=\frac{\mathrm{QT}_{\text {off }}}{\overline{\mathrm{Z}} \mathrm{L}}----
$$

where $\mathrm{w}$ is average width of flow in furrow in $\mathrm{m}, \mathrm{Q}$ is furrow inflow rate in $\mathrm{m}^{3} / \mathrm{h}$, $\mathrm{T}_{\text {off }}$ is water cutoff time in $\mathrm{h}, \overline{\mathrm{Z}}$ is average of cumulative infiltrated depth in $\mathrm{m}$, and $\mathrm{L}$ is furrow length in $\mathrm{m}$.

To evaluate the border and furrow irrigation treatments, the distribution uniformity was taken as a function of coefficient of variation (CV) as follows:

$$
\mathrm{DU}=1-1.27 \mathrm{CV}-----(8)
$$

Application efficiency $\left(E_{a}\right)$ was determined based on complete surplus irrigation situation. Therefore, the schedule depth (d) was taken equal to the minimum infiltrated water depth $\left(\mathrm{Z}_{\mathrm{min}}\right)$. The application efficiency $\left(E_{a}\right)$ which defined as the ratio of the amount of irrigation stored in the root zone to the total water applied was determined as follows:

$$
\mathrm{E}_{\mathrm{a}}=\frac{\mathrm{d}}{\overline{\mathrm{Z}}} \text {---- }
$$

where $\mathrm{d}$ was the schedule depth which was taken equal to the minimum infiltrated depth $\left(Z_{\min }\right)$ in $\mathrm{mm}$ and $\bar{Z}$ was the average infiltrated depth along the strip or the furrow in $\mathrm{mm}$.

As grape rootzone depth was measured to $1.5 \mathrm{~m}$, the maximum soil storage water depth $\left(\mathrm{d}_{\max }\right)$ was determined based on the difference 
between volumetric soil moisture content before and after irrigation times the rootzone depth. In complete surplus irrigation situation, water depth used by plant per irrigation was taken equal to minimum infiltrated depth $\left(Z_{m i n}\right)$. Irrigation interval for border $\left(I=Z_{\min } / E_{c}\right)$ was determined based on peak daily grape water use $\left(\mathrm{ET}_{\mathrm{c}}\right)$ which was recorded $5 \mathrm{~mm}$ in the region. The vegetative covered area by grape was measured as $1.36 \mathrm{~m}$ average width for $60 \mathrm{~m}$ length. Irrigation interval by furrow was determined as follows:

$$
\mathrm{I}=\frac{\mathrm{W} \mathrm{Z} \mathrm{Z}_{\min }}{\mathrm{W} \mathrm{ET}_{\mathrm{c}}}------(10)
$$

where $\mathrm{W}$ was average vegetable cover width in $\mathrm{m}$, $\mathrm{w}$ in $\mathrm{m}, \mathrm{Z}_{\min }$ in $\mathrm{mm}$, and $\mathrm{ET}_{\mathrm{c}}$ in $\mathrm{mm}$.

\section{RESULTS AND DISCUSSION}

\section{Independent infiltration rate}

The rate of infiltration was considered as a time dependent process and represented by Kostiakov's equation. Field infiltration rate was presented in the curves in Fig. 4. The soils at the three locations were moderately dried at the surface prior to infiltration about $21 \%$ water by weight. Measured intake rates for individual infiltration runs were obtained at 2to 10-minute intervals for the duplicate measurement locations at each of three sites. The average points in the figure were taken from duplicate measured curves (different locations) at regular time intervals; the vertical bar at each point showed the difference between duplicate curves at a given time. The precision of these measurements was excellent considering potential soil variation between measurement locations at a given site and the likelihood of errors in infiltration measurements. Infiltration rate (I in $\mathrm{mm} / \mathrm{h}$ ) as fitted to Kostiakov equation was found in the experimental field. It was functioned to opportunity time $t_{\mathrm{o}}$ in minute for the clay loam soil as $I=360 t_{o}^{-0.498}$ with $r^{2}=0.97$. The minimum value of $18 \mathrm{~mm} / \mathrm{h}$ infiltration rate was found. Cumulative infiltrated depth $\mathrm{Z}$ in $\mathrm{mm}$ was integrated from infiltration rate function and reported as $Z=12$ $\mathrm{t}_{\mathrm{o}}{ }^{0.502}$, where $\mathrm{Z}$ in $\mathrm{mm}$ and $\mathrm{t}_{\mathrm{o}}$ in $\min$. 


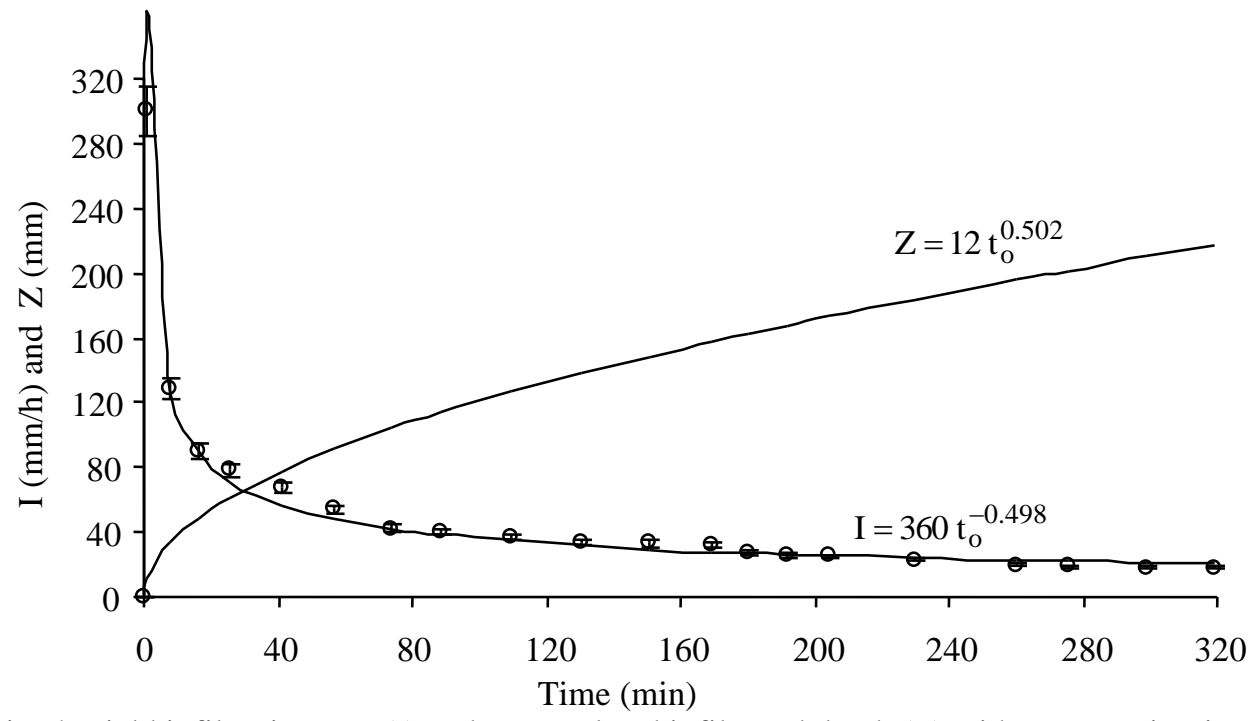

Fig. 4: Field infiltration rate (I) and accumulated infiltrated depth (Z) with opportunity time.

\section{Water advance and recession as affected by inflow rate}

Border advance and recession times as shown in Fig. 5 were functioned of their lengths by applying three inflow rates $24.7 \%$ initial soil moisture content and zero storage stage time. Water was cutoff $\left(\mathrm{T}_{\text {off }}\right)$ when water flow was exactly reached the field end. Total advance time $\left(\mathrm{t}_{\mathrm{L}}\right)$ was recorded as 28.0, 21.0, and $15.4 \mathrm{~min}$ at $9.8,12.0$, and $15.5 \mathrm{~m}^{2} / \mathrm{h}$ inflow rate, respectively. Depletion time was found to be 2,6 , and $10 \mathrm{~min}$, respectively. Total time ( $\mathrm{T})$ which included advance, storage, and depletion phases was 30,27 , and 25.4 min, respectively. Total recession time $t_{R}$ was found to be 48, 37, and 25.6 min, respectively. Curves in Fig. 5 showed that advance and recession times were decreased by increasing their inflow rates. On the contrary, depletion phase time was increased with the increase of inflow rate due to reducing the advance stage duration when water was applied. Empirical power forms were obtained by regression $\left(\mathrm{r}^{2} \geq 0.96\right)$ for the measured advance time $\left(\mathrm{t}_{\ell}\right)$ versus border length $(\ell)$ of border with blocked-end yielding $\mathrm{t}_{\ell}=0.045 \ell^{1.55}, \mathrm{t}_{\ell}=0.0448$ $\ell^{1.47}$, and $\mathrm{t}_{\ell}=0.0456 \ell^{1.4}$ by applying $9.8,12.0$, and $15.5 \mathrm{~m}^{2} / \mathrm{h}$ inflow rate, respectively. It was noticed that the power coefficient of the advance function was decreased when inflow rate was increased, but the constant coefficient was practically the same value. While the water recession time was described as: $\mathrm{t}_{\mathrm{r}}=0.3215 \ell^{1.223}, \mathrm{t}_{\mathrm{r}}=0.243 \ell^{1.22}$, and $\mathrm{t}_{\mathrm{r}}=0.18 \ell^{1.19}$, 
respectively. It was seemed that the slope of the recession function was about the same value, on the other hand, the intercept was decreased when inflow rate was increased.

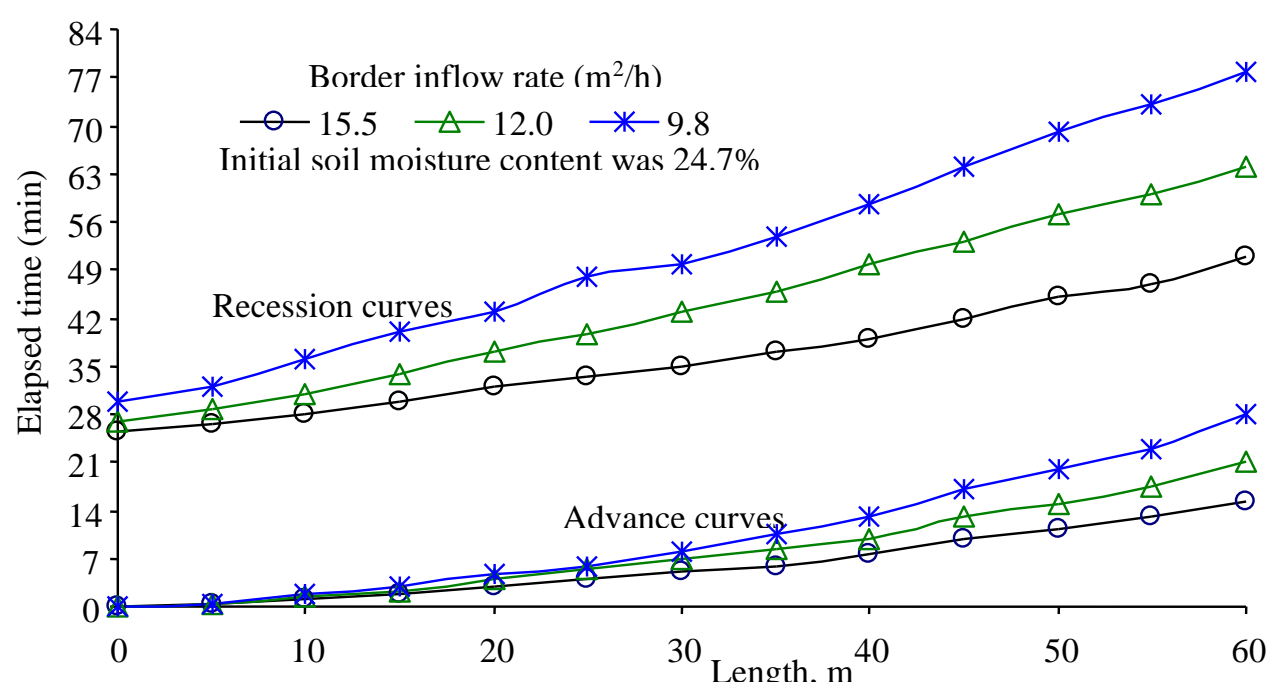

Fig. 5: Border water advance and recession as affected by inflow rate.

In new technique of furrow irrigation, advance and recession times (Fig. 6 ) were increased by increasing their inflow rates that were applied when initial soil moisture content by weight was $25.1 \%$ and water cutoff was adjusted to include only advance phase. Cutoff time ( $\mathrm{T}_{\text {off }}$ ) as well as total advance time $\left(\mathrm{t}_{\mathrm{L}}\right)$ was recorded as $56,42,28$ min when inlet flow was applied as $2.2,3$, and $4 \mathrm{~m}^{3} / \mathrm{h}$, respectively. Depletion time was 3, 9.2, and $12 \mathrm{~min}$, respectively. Total time (T) was 59, 51.2, and $40 \mathrm{~min}$, respectively. Total recession time $\left(\mathrm{t}_{\mathrm{R}}\right)$ was found to be $37,32.8$, and 31.6 min, respectively. Results showed that total recession time was insignificantly affected by 3 and $4 \mathrm{~m}^{3} / \mathrm{h}$ inflow rates. It was seemed that the trend of the results in furrow was almost similar as in border irrigation except the duration of irrigation was longer in furrow than in border. Regarding to applying low inlet flows into furrows compared to borders, not many significant differences in parameters relationship were occurred. Empirical equations were obtained using linear regression $\left(r^{2} \geq 0.971\right)$ for the measured advance time $\left(\mathrm{t}_{\ell}\right)$ against furrow length $(\ell)$ as: $\mathrm{t}_{\ell}=0.09 \ell^{1.57}$, $\mathrm{t}_{\ell}=0.09 \ell^{1.5}$, and $\mathrm{t}_{\ell}=0.09 \ell^{1.41}$ by applying $2.2,3$, and $4 \mathrm{~m}^{3} / \mathrm{h}$ inflow rate, respectively. Results in the advance forms showed that the power (m) was 
significantly increased by decreasing inflow rates, but, the constant (a) was intentionally set the same. While the water recession time was defined as: $\mathrm{t}_{\mathrm{r}}=0.23 \ell^{1.241}, \mathrm{t}_{\mathrm{r}}=0.205 \ell^{1.24}$, and $\mathrm{t}_{\mathrm{r}}=0.197 \ell^{1.24}$, respectively. It was seemed that the constant coefficient (c) of recession function was decreased by increasing inflow rate, but the power coefficient (x) was intentionally selected the closed value.

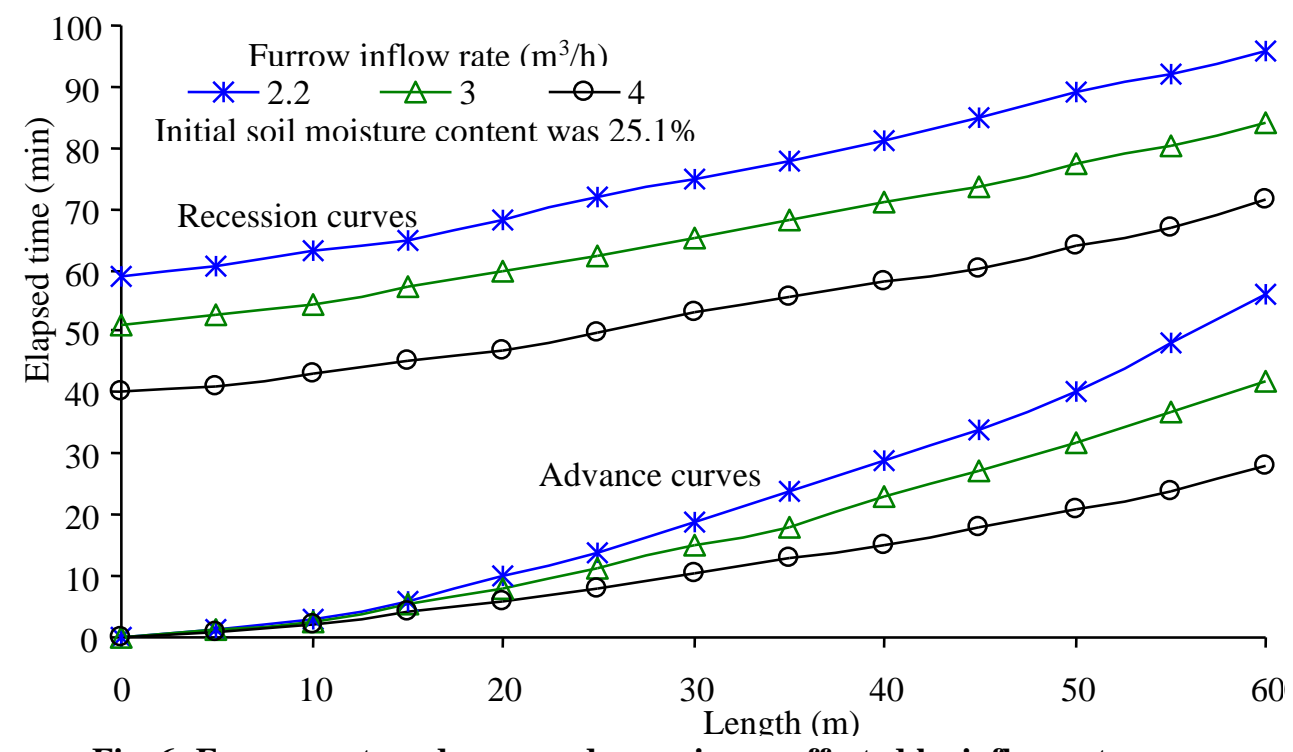

Fig. 6: Furrow water advance and recession as affected by inflow rate.

\section{Water advance and recession as affected by soil moisture content}

Border advance and recession times as shown in Fig. 7 were functioned of their lengths by applying $9.8 \mathrm{~m}^{2} / \mathrm{h}$ inflow rate when soil was initialized as $21.4,24.7$, and $27.1 \%$ moisture content by weight. Total advance time $\left(\mathrm{t}_{\mathrm{L}}\right)$ as well as water cutoff time ( $\left.\mathrm{T}_{\text {off }}\right)$ was recorded as $40.2,28.0$, and 18.6 min when average of initial soil moisture content by weight was 21.4, 24.7 , and $27.1 \%$, respectively. As storage phase was zero, depletion time was found to be $12.8,2.0$, and $0.5 \mathrm{~min}$, respectively. Total time (T) was 53, 30, and $19.1 \mathrm{~min}$, respectively. Total recession time $\left(\mathrm{t}_{\mathrm{R}}\right)$ was found to be 94, 51, and $15.5 \mathrm{~min}$, respectively. Curves in Fig. 7 showed that advance and recession times were increased when initial soil moisture was low. On the other hand, depletion phase time was decreased with the increase of initial soil moisture content in which caused low stored water in the advance stage. Empirical power equations were obtained by 
regression $\left(\mathrm{r}^{2} \geq 0.97\right)$ for measured advance data as: $\mathrm{t}_{\ell}=0.08 \ell^{1.57}, \mathrm{t}_{\ell}=$ $0.071 \ell^{1.426}$, and $\mathrm{t}_{\ell}=0.093 \ell^{1.2735}$ by applying $21.4,24.7$, and $27.1 \%$ moisture content by weight, respectively. It was evident that the power coefficient (m) of the advance function was decreased with the increase of initial moisture content, but the constant coefficient (a) was valued around 0.082 by \pm 0.011 . While the water recession time was described as: $t_{r}=$ $0.65 \ell^{1.276}, \mathrm{t}_{\mathrm{r}}=0.2614 \ell^{1.277}$, and $\mathrm{t}_{\mathrm{r}}=0.0765 \ell^{1.283}$, respectively. It was obvious that the constant coefficient (c) of the recession function was decreased with the increase of the initial soil moisture content, but the power coefficient $(\mathrm{x})$ was significantly not.

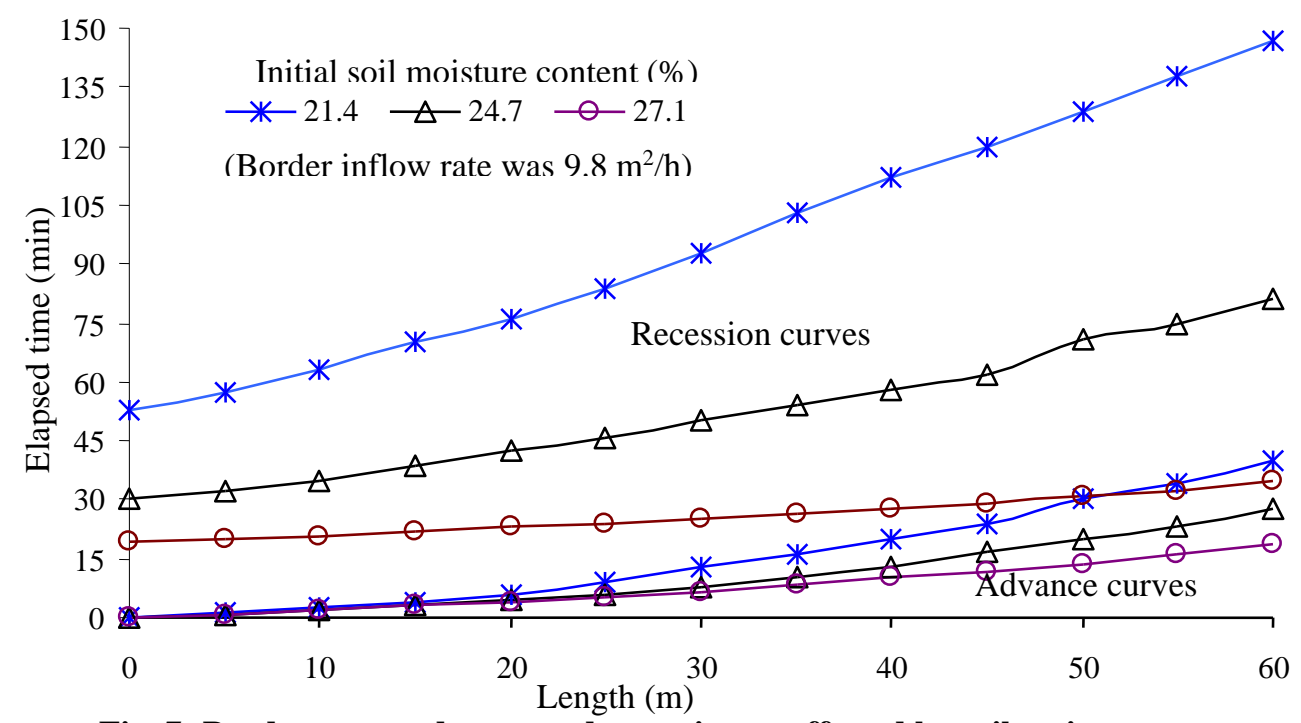

Fig. 7: Border water advance and recession as affected by soil moisture content.

Furrow irrigation advance and recession times versus their lengths recorded by applying $2.2 \mathrm{~m}^{3} / \mathrm{h}$ inflow rate for three different initial soil moisture contents by weight were illustrated in Fig. 8. Time of water cutoff $\left(\mathrm{T}_{\text {off }}\right)$ as well as time of total water advance $\left(\mathrm{t}_{\mathrm{L}}\right)$ was recorded as 106, 53, and $37 \mathrm{~min}$ at 22.7, 25.4, and $27.2 \%$ initial soil moisture content, respectively. Depletion time was 4,4 , and $5 \mathrm{~min}$, respectively. Total recession time $\left(t_{R}\right)$ was 53,37 , and 33 min, respectively. Results showed that advance and recession times were decreased with the increase of moisture content. Depletion time was insignificantly affected by moisture content due to low inflow rate in furrow compared to that in border. Empirical power equations were obtained by regression $\left(r^{2} \geq 0.974\right)$ for 
furrow advance time yielding $\mathrm{t}_{\ell}=0.089 \ell^{1.74}, \mathrm{t}_{\ell}=0.076 \ell^{1.61}$, and $\mathrm{t}_{\ell}=$ $0.0895 \ell^{1.47}$ by applying $22.7,25.4$, and $27.2 \%$ moisture content by weight, respectively. It was seemed that the power coefficient $(\mathrm{m})$ of the advance function decreased when initial moisture content was increased, but the constant coefficient (a) was around 0.084 by \pm 0.008 . While the water recession time was described as: $\mathrm{t}_{\mathrm{r}}=0.46 \ell^{1.16}, \mathrm{t}_{\mathrm{r}}=0.32 \ell^{1.164}$, and $\mathrm{t}_{\mathrm{r}}$ $=0.258 \ell^{1.16}$, respectively. It was noticed that the constant coefficient (c) of recession function was decreased by increasing initial soil moisture content, but the power coefficient $(\mathrm{x})$ was almost remained the same.

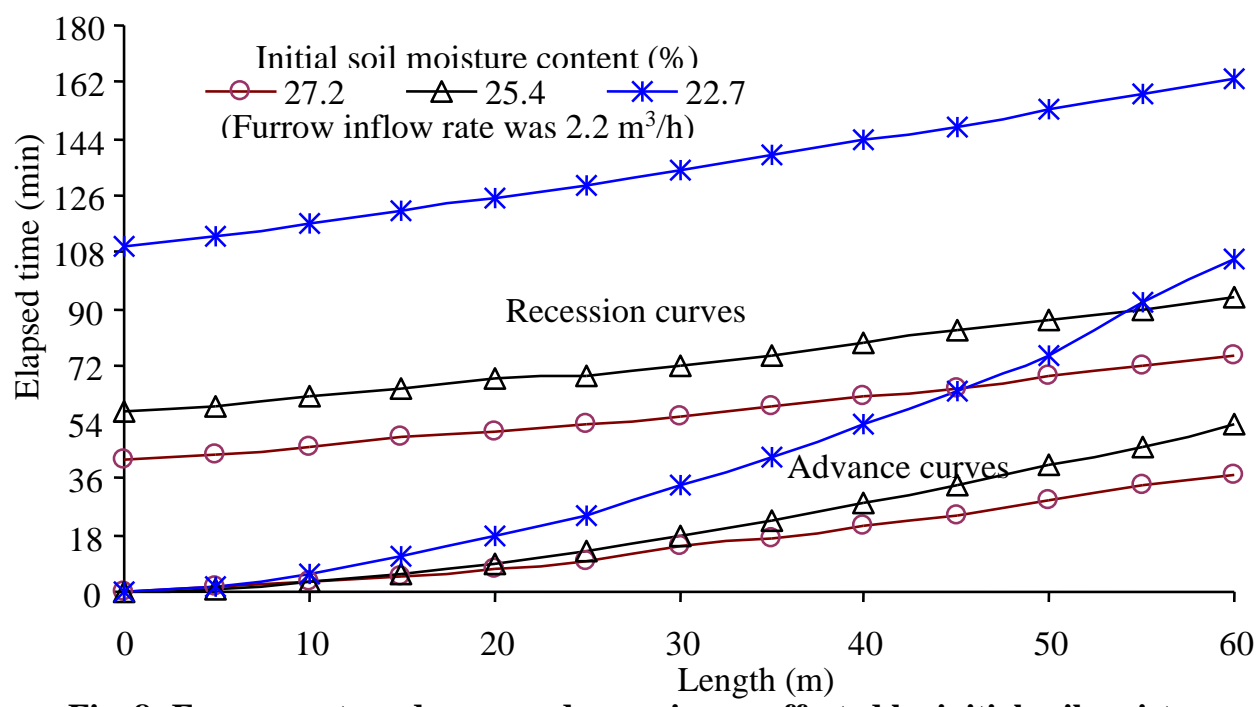

Fig. 8: Furrow water advance and recession as affected bv initial soil moisture.

\section{Infiltrated water depth as affected by inflow rate}

Border infiltrated depth as affected by three different inflow rates when soil was initialized as $24.7 \%$ moisture content by weight was illustrated in Fig. 9. Infiltrated depth was increased when inflow rate was low due to slowly water movement along border strip. Minimum infiltrated depth $\left(Z_{\min }\right)$ where occurred at the upstream end was $66.2,62.8$, and $60.9 \mathrm{~mm}$ by applying $9.8,12.0$, and $15.5 \mathrm{~m}^{2} / \mathrm{h}$ inflow rate, respectively. Maximum infiltrated depth $\left(\mathrm{Z}_{\max }\right)$ where occurred at the downstream end was 87.6, 80.6, and $71.3 \mathrm{~mm}$, respectively. Average depth $(\bar{Z})$ was 77.6, 72.0 and $66.4 \mathrm{~mm}$, respectively. Curves in Fig. 9 showed that water depth was increased along with strip length because total recession time $\left(t_{R}\right)$ was larger than total advance time $\left(t_{\mathrm{L}}\right)$. Correlations between field and 
determined depths were highly obtained with zero intercept, nearly unity slope, and $\mathrm{r}^{2} \geq 0.971$. Coefficient of variation (CV) was 9.1, 8.2, and 5.2 $\%$, respectively. Distribution uniformity (DU) was 88.5, 89.6, and 93.5\%, respectively. According to the results of $\mathrm{CV}$ and DU, the best water distribution was acquired for $15.5 \mathrm{~m}^{2} / \mathrm{h}$ inflow rate treatment. As initial soil moisture content by weight was $24.7 \%$ before and $32 \%$ after irrigation, average bulk density was $1.3 \mathrm{~g} / \mathrm{cm}^{3}$, and rootzone depth was $1.5 \mathrm{~m}$, the maximum soil water storage depth in rootzone was determined as $142.4 \mathrm{~mm}$. Therefore, the schedule irrigation depth (d) which was less than the maximum soil storage depth $\left(\mathrm{d}_{\max }\right)$ was taken equal to the minimum infiltrated depth $\left(\mathrm{Z}_{\min }\right)$. The schedule depth $(\mathrm{d})$ was compared with water depth uptake by plant on order to evaluate irrigation system scheduling as synchronizing with its design parameters. Therefore, application efficiency $\left(\mathrm{E}_{\mathrm{a}}\right)$ was determined as $85.3,87.2$, and $91.7 \%$ by applying $9.8,12.0$, and $15.5 \mathrm{~m}^{2} / \mathrm{h}$ inflow rate, respectively. Irrigation interval was 13.2, 12.6, and 12.2 day, respectively. Results showed that $\mathrm{CV}, \mathrm{DU}$, and $\mathrm{E}_{\mathrm{a}}$ were improved with the increase of inflow rate.

Furrow infiltrated depth as affected by inflow rate when soil was initialized as $25.1 \%$ gravimetric soil moisture content was shown in Fig. 10. Average depth $(\bar{Z})$ was $88.3,84.6$ and $76.5 \mathrm{~mm}$ by applying $2.2,3$, and $4 \mathrm{~m}^{3} / \mathrm{h}$ inflow rate, respectively. Minimum depth $\left(\mathrm{Z}_{\mathrm{min}}\right)$ was 76.8 , 78.6, and $76.5 \mathrm{~mm}$, respectively. Maximum depth $\left(\mathrm{Z}_{\max }\right)$ was $92.9,86.5$, and $79.0 \mathrm{~mm}$, respectively. Maximum depth by applying 2.2 and $3 \mathrm{~m}^{3} / \mathrm{h}$ was occurred at downstream end because total advance time $\left(t_{\mathrm{L}}\right)$ was larger than total recession time $\left(t_{R}\right)$, but, it wasn't by $4 \mathrm{~m}^{3} / \mathrm{h}$ inflow rate. There was no significant deference among minimum depths, but it was significantly among maximum depths. Coefficient of variation (CV) was 6.4, 3.4, and 1.1\%, respectively. Distribution uniformity (DU) was 91.9, 95.7, and $98.6 \%$, respectively. Infiltrated depth was increased, but with less water uniform, when inflow rate was low. Based on the results of CV and DU, the best water distribution was fitted to $4 \mathrm{~m}^{3} / \mathrm{h}$ inflow rate treatment within initial soil moisture content treatment. Maximum soil water storage depth $\left(\mathrm{d}_{\max }\right)$ in rootzone was determined as $134.6 \mathrm{~mm}$. Schedule irrigation depth (d) which was less than maximum soil storage 
depth was taken equal minimum infiltrated depth $\left(Z_{\min }\right)$. Therefore, application efficiency $\left(E_{a}\right)$ was determined as $86.9,92.9$, and $97.6 \%$ by applying $2.2,3$, and $4 \mathrm{~m}^{3} / \mathrm{h}$ inflow rate, respectively. Average infiltrated water width (w) was calculated using Eq.7 as 0.388, 0.414, and $0.397 \mathrm{~m}$, respectively. Irrigation interval was 4.4, 4.8, and 4.5 day, respectively. Results showed that average furrow water width (w) was insignificantly affected by change of inflow rate within initial soil moisture treatment. $\mathrm{CV}, \mathrm{DU}$, and $\mathrm{E}_{\mathrm{a}}$ were highly improved with the increase of inflow rate.

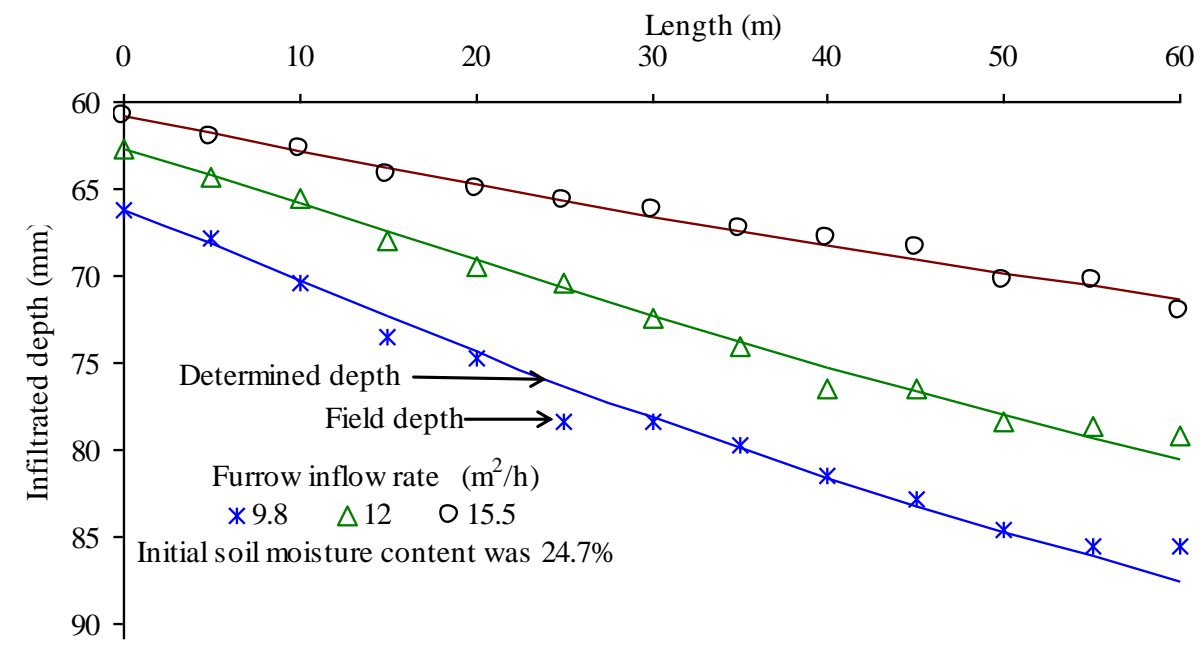

Fig. 9: Border infiltrated depth as affected by inflow rate.

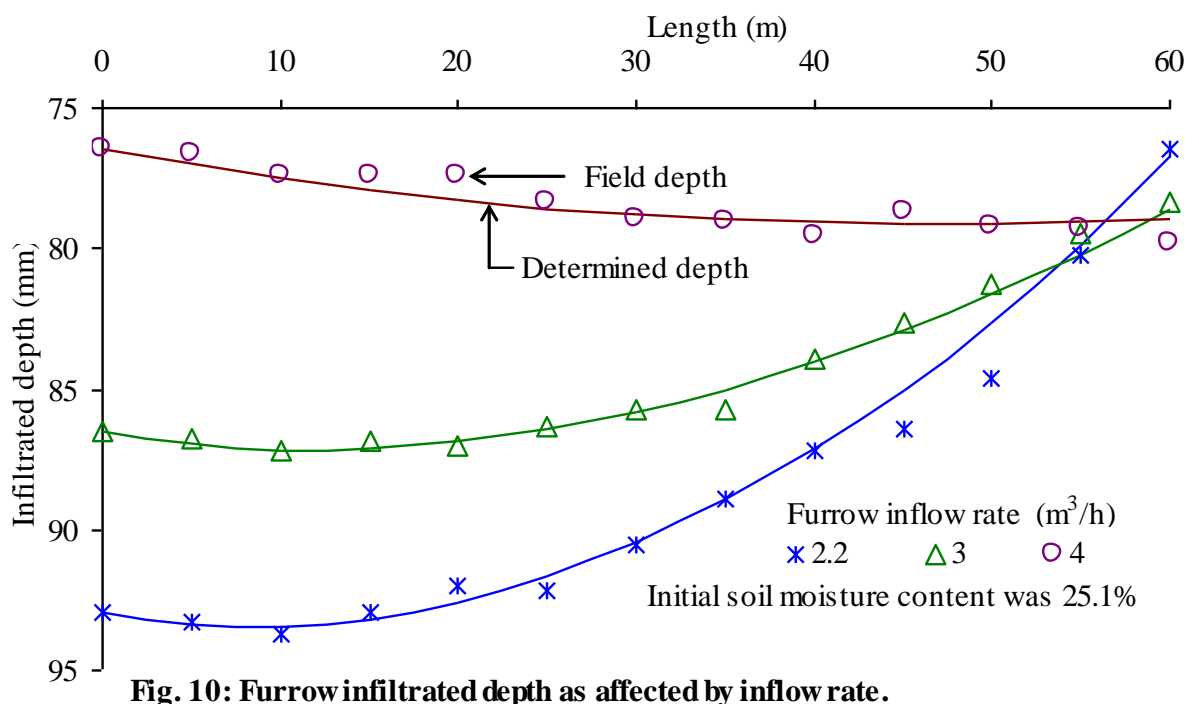




\section{Infiltrated water depth as affected by initial soil moisture content}

Border infiltrated depth as affected by initial soil moisture content within $9.8 \mathrm{~m}^{2} / \mathrm{h}$ inflow rate was illustrated in Fig. 11 .

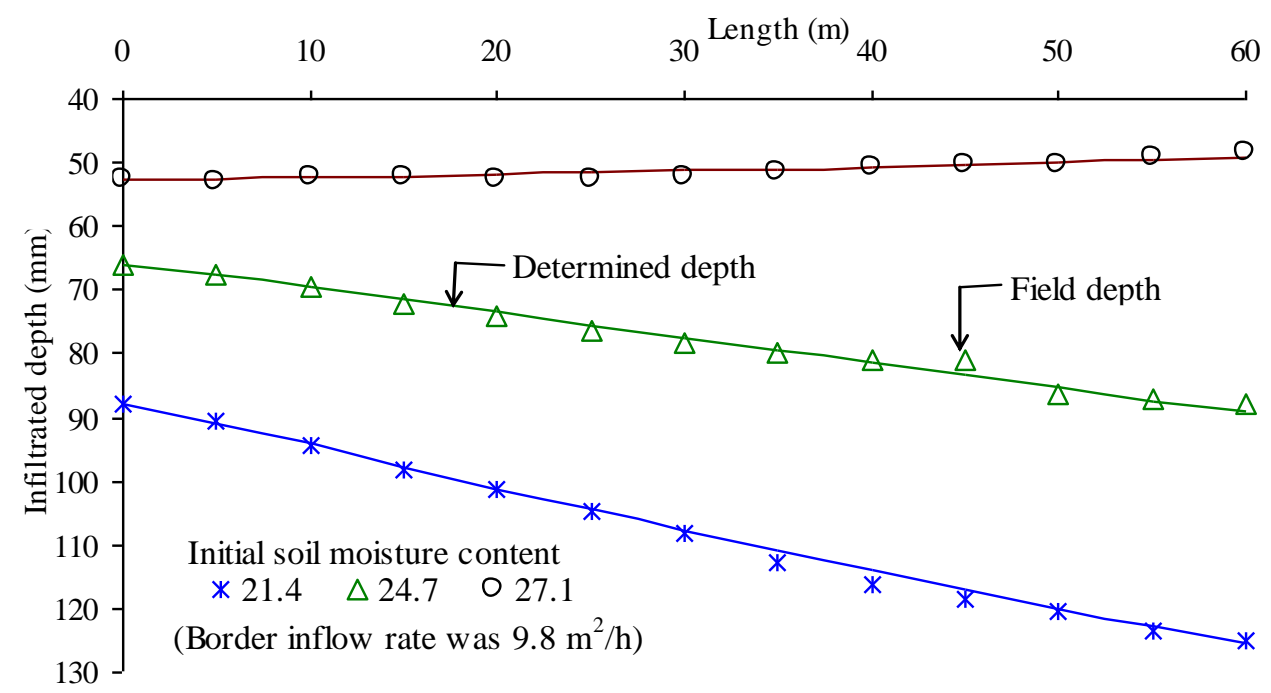

Fig. 11: Border infiltrated depth as affected by initial soil moisture content.

Infiltrated depth was increased, but with less water uniform, when soil moisture content was low. Minimum infiltrated depth $\left(\mathrm{Z}_{\mathrm{min}}\right)$ was 88.1, 66.2 , and $49.2 \mathrm{~mm}$ for $21.4,24.7$, and $27.1 \%$ soil moisture content by weight, respectively. Maximum infiltrated depth $\left(Z_{\max }\right)$ was $125.6,89.2$, and $52.8 \mathrm{~mm}$, respectively. Average depth $(\bar{Z})$ was $107.39,77.5$ and 51.2 $\mathrm{mm}$, respectively. It was noticed that $Z_{\min }$ nearly equal to $Z_{\max }$ by $27.1 \%$ moisture treatment, so water depth along border was uniformly distributed. Maximum depth by $27.1 \%$ treatment was occurred at the downstream end, but it was happened by 21.4 and $24.7 \%$ treatments on the upstream end. Coefficient of variation $(\mathrm{CV})$ was $11.6,9.8$, and $2.3 \%$ for 21.4, 24.7, and 27.1\% gravimetric moisture content, respectively. Distribution uniformity (DU) was 85.3, 87.5, and 97.1\%, respectively. According to the results of $\mathrm{CV}$ and DU, the best water distribution was observed for $27.1 \%$ moisture treatment. Maximum soil water storage depth $\left(\mathrm{d}_{\max }\right)$ in rootzone was determined as $206.7,142.4$, and $95.6 \mathrm{~mm}$, at 21.4, 24.7, and $27.1 \%$ moisture by weight, respectively. Schedule irrigation depth (d) which was taken equal to $Z_{\min }$ was less than $d_{\max }$. Therefore, application efficiency $\left(\mathrm{E}_{\mathrm{a}}\right)$ was determined as 82.1, 85.4, and 
96.2\%, respectively. Irrigation interval was 17.6, 13.2, and 10.6 day, respectively. Results showed that border irrigation was highly performed by applying water when soil was initialized with an adequate amount of moisture content.

Furrow infiltrated depth as affected by three initial soil moisture contents, when inflow rate was applied as $2.2 \mathrm{~m}^{3} / \mathrm{h}$, was shown in Fig. 12 .

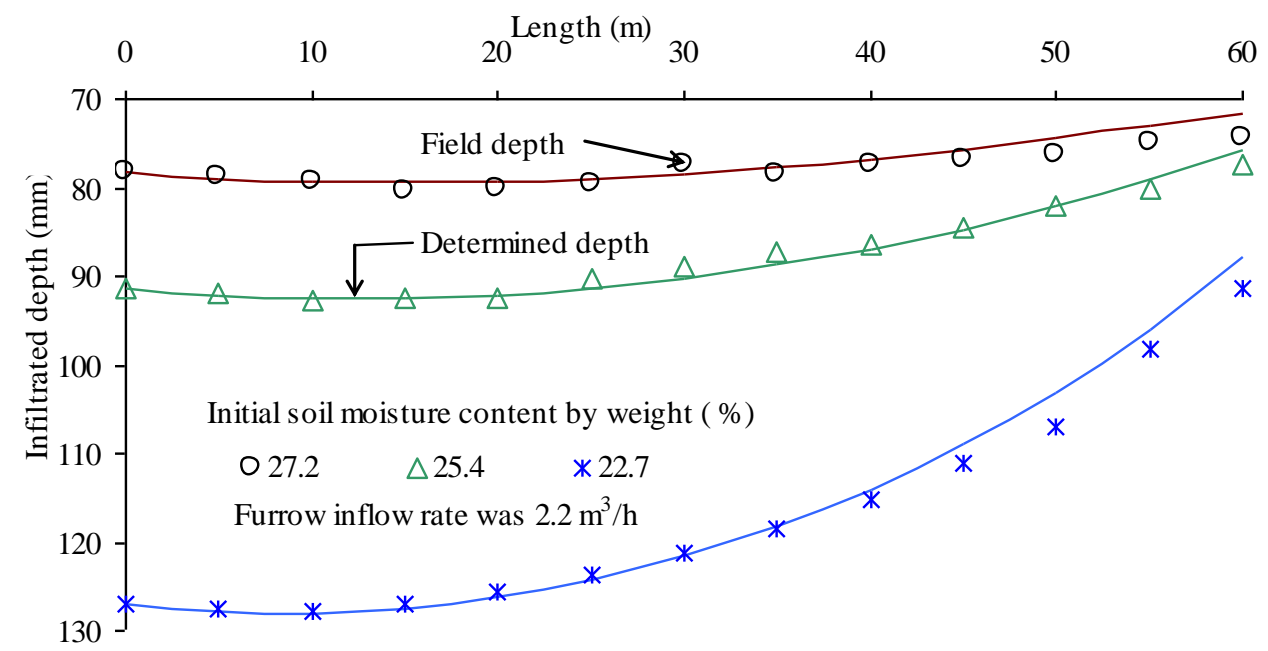

Fig. 12: Furrow infiltrated depth as affected by initial soil moisture content.

Infiltrated depth was increased when soil moisture was low. Average depth $(\bar{Z})$ was $116.2,87.7$ and $77.1 \mathrm{~mm}$ by applying $22.7,25.4$, and $27.2 \%$ soil moisture by weight, respectively. Minimum depth $\left(Z_{\min }\right)$ was 87.8, 75.6, and $71.5 \mathrm{~mm}$, respectively. Maximum depth $\left(\mathrm{Z}_{\max }\right)$ was 127.0, 91.3 and $78.4 \mathrm{~mm}$, respectively. Maximum depths were occurred at the beginning of downstream end because total advance time $\left(t_{L}\right)$ was larger than total recession time $\left(t_{R}\right)$.

Coefficient of variation (CV) was $11.5,6.4$, and 3.4\%, respectively. Distribution uniformity (DU) was $85.3,91.8$, and $95.7 \%$, respectively. Based on the results of $\mathrm{CV}$ and DU, the best water distribution was acquired at $27.2 \%$ soil moisture treatment. Maximum soil water storage depth $\left(\mathrm{d}_{\max }\right)$ in rootzone was determined as $181.4,128.7$, and $93.6 \mathrm{~mm}$ by applying $22.7,25.4$, and $27.2 \%$ soil moisture by weight, respectively. Schedule irrigation depth (d) which was less than $d_{\max }$ was taken equal to $\mathrm{Z}_{\min }$ in complete surplus irrigation. Therefore, application efficiency $\left(\mathrm{E}_{\mathrm{a}}\right)$ 
was determined as 75.5, 86.3, and 92.8\%, respectively. Average infiltrated water width (w) was calculated using Eq.7 as 0.558, 0.380, and $0.293 \mathrm{~m}$, respectively. Results showed that average furrow water width was significantly increased with the decrease of initial soil moisture content. Irrigation interval was determined as 7.2, 4.1, and 3.1 day, respectively. Results indicated that the larger the moisture content or the slower the inflow rate was treated, the larger amount of water applied or the longer irrigation interval was occurred. Surface irrigation was improved by selecting the suitable inflow rate and initial soil moisture content.

\subsection{Improving border irrigation system by changing storage phase time}

Border irrigation as improved by storage phase time within inflow rate treatment was shown in Table 2. Depletion phase time $\left(\mathrm{T}_{\mathrm{d}}\right)$ was generally increased with the increase of storage phase time $\left(\mathrm{T}_{\mathrm{s}}\right)$. Schedule depth $(\mathrm{d})$ was less than soil storage depth $\left(\mathrm{d}_{\max }\right)$. Infiltrated water depth was also increased by increasing $T_{s}$ within inflow rate treatment. $C V, D U$, and $E_{a}$ were improved by increasing $\mathrm{T}_{\mathrm{s}}$ from 0 to $10 \mathrm{~min}$ as shown in Table 2. the best values were achieved as $\leq 5.1 \%$ for $\mathrm{CV}, \geq 93.6 \%$ for $\mathrm{DU}$, and 91.75 for $E_{\text {a }}$ by increasing $\mathrm{T}_{\mathrm{s}}$ from 0 to $10 \mathrm{~min}$ within $15.5 \mathrm{~m}^{2} / \mathrm{h}$ inflow rate. Irrigation interval was extended from 13.2 to 19.1 day by increasing $T_{\mathrm{s}}$ from 0 to $10 \mathrm{~min}$ within $9.8 \mathrm{~m}^{2} / \mathrm{h}$ inflow rate treatment. It was from 12.2 to 21.2 when $\mathrm{T}_{\mathrm{s}}$ was increased from 0 to $10 \mathrm{~min}$ within $15.5 \mathrm{~m}^{2} / \mathrm{h}$ treatment. It was obvious that irrigation interval was become longer in large inflow rate than in small inflow by applying $10 \mathrm{~min} \mathrm{~T}_{\mathrm{s}}$ compared to $0 \mathrm{~min} \mathrm{~T}_{\mathrm{s}}$ due to large amount of water applied in storage phase. Water use (WU) was decreased by increasing both inflow rate and storage phase time. For example, water saving was achieved as $12 \%$ by applying 15.5 $\mathrm{m}^{2} / \mathrm{h}$ with $10 \mathrm{~min} \mathrm{~T}_{\mathrm{s}}$ treatment compared to $9.8 \mathrm{~m}^{2} / \mathrm{h}$ with $10 \mathrm{~min} \mathrm{~T}_{\mathrm{s}}$ treatment from grape water use. Grape yield was increased by increasing both inflow rate and storage phase time. The increase rate was in range from 2.4 to $3.1 \mathrm{Mg} /$ ha within $\mathrm{T}_{\mathrm{s}}$ treatment. It was from 0.87 to $2 \mathrm{Mg} / \mathrm{ha}$ within inflow rate treatment. 
Table 2: Border irrigation as improved by three storage phase times within inflow rate.

\begin{tabular}{|c|c|c|c|c|c|c|c|c|c|}
\hline \multirow{2}{*}{$\begin{array}{c}\text { Evaluating } \\
\text { parameters }\end{array}$} & \multicolumn{9}{|c|}{ Inflow rate per unit width $\left(\mathrm{m}^{2} / \mathrm{h}\right)$} \\
\cline { 2 - 11 } & \multicolumn{3}{|c|}{9.8} & \multicolumn{3}{|c|}{12.0} & \multicolumn{3}{c|}{15.5} \\
\hline $\mathrm{T}_{\mathrm{s}}(\mathrm{min})$ & 0 & 5 & 10 & 0 & 5 & 10 & 0 & 5 & 10 \\
\hline $\mathrm{T}_{\mathrm{d}}(\mathrm{min})$ & 2.0 & 11.2 & 24.1 & 6.0 & 17.1 & 33.1 & 10.0 & 27.6 & 51.3 \\
\hline $\mathrm{T}_{\text {off }}(\mathrm{min})$ & 28.0 & 33.0 & 38.0 & 21.0 & 26.0 & 31.0 & 15.4 & 20.4 & 25.4 \\
\hline $\mathrm{d}(\mathrm{mm})$ & 66.2 & 80.4 & 95.3 & 62.8 & 79.4 & 96.9 & 60.9 & 83.8 & 106.0 \\
\hline $\bar{Z}(\mathrm{~mm})$ & 77.6 & 90.1 & 103.7 & 72.0 & 86.9 & 103.2 & 66.4 & 87.9 & 109.3 \\
\hline $\mathrm{CV}(\%)$ & 9.1 & 6.7 & 5.1 & 8.2 & 5.6 & 4.0 & 5.2 & 2.9 & 1.9 \\
\hline $\mathrm{DU}(\%)$ & 88.5 & 91.5 & 93.6 & 89.6 & 92.9 & 95.0 & 93.5 & 96.3 & 97.6 \\
\hline $\mathrm{E}_{\mathrm{a}}(\%)$ & 85.3 & 89.2 & 91.9 & 87.2 & 91.3 & 93.9 & 91.7 & 95.3 & 97.0 \\
\hline $\mathrm{I}(\mathrm{d})$ & 13.2 & 16.1 & 19.1 & 12.6 & 15.9 & 19.4 & 12.2 & 16.8 & 21.2 \\
\hline $\mathrm{WU}\left(\mathrm{m}^{3} / \mathrm{ha} / \mathrm{d}\right)$ & 58.6 & 56.1 & 54.4 & 57.4 & 54.8 & 53.3 & 54.5 & 52.5 & 51.6 \\
\hline Yield (Mg/ha) & 28.97 & 30.78 & 32.02 & 29.85 & 31.4 & 32.91 & 31.92 & 33.57 & 34.33 \\
\hline
\end{tabular}

${ }^{*} \mathrm{~T}_{\mathrm{s}}$ is storage phase time, $\mathrm{T}_{\mathrm{d}}$ is depletion phase time, $\mathrm{T}_{\text {off }}$ is water cutoff time, $\mathrm{d}$ is schedule depth, $\bar{Z}$ is average infiltrated depth, $C V$ is coefficient of variation, DU is distribution efficiency, $E_{a}$ is application efficiency, I is irrigation interval, and WU is water use.

Border irrigation evaluation and scheduling parameters were improved by the increase of storage phase time $\left(\mathrm{T}_{\mathrm{s}}\right)$ from 0 to $10 \mathrm{~min}$ within soil moisture treatment as was shown in Table 3. Times of depletion phase and water cutoff were increased by increasing $\mathrm{T}_{\mathrm{s}}$ within moisture treatment. Maximum soil water storage depth $\left(\mathrm{d}_{\max }\right)$ was determined for $1.5 \mathrm{~m}$ rootzone depth as 207, 142.4, and $95.6 \mathrm{~mm}$ at 21.4, 24.7, and $27.1 \%$ initial soil moisture content by weight, respectively. The schedule irrigation depth (d) was commonly taken equal to the minimum infiltrated depth to achieve complete surplus irrigation condition. In turn, $d$ was less than $d_{\max }$, so the irrigation situation was been as planned. Coefficient of variation $(\mathrm{CV})$ as well as distribution efficiency (DU) was achieved better value $(\mathrm{CV} \leq 2.3 \%$ and $\mathrm{DU} \geq 97.1 \%)$ by increasing $\mathrm{T}_{\mathrm{s}}$ from 0 to $10 \mathrm{~min}$. $E_{a}$ was improved by increasing initial moisture within $T_{s}$ treatment; furthermore, it was improved by the increase of $\mathrm{T}_{\mathrm{s}}$ within moisture treatment. Water saving was grown from 0 to $19 \%$ by increasing initial moisture content by weight from 21.4 to $27.1 \%$ and storage phase time from 0 to $10 \mathrm{~min}$, respectively. Grape yield was increased with increasing both initial soil moisture and storage phase time. The increase rate reached $3.11 \mathrm{Mg} / \mathrm{ha}$ when $\mathrm{T}_{\mathrm{s}}$ was changed from 0 to $10 \mathrm{~min}$ within $21.4 \%$ 
soil moisture content. It reached $8.6 \mathrm{Mg} / \mathrm{ha}$ by increasing soil moisture content from 21.4 to $27.1 \%$ within no storage phase treatment.

Table 3: Border irrigation as improved by three storage phase times within soil moisture.

\begin{tabular}{|c|c|c|c|c|c|c|c|c|c|}
\hline \multirow{2}{*}{$\begin{array}{c}\text { Evaluating } \\
\text { parameters }\end{array}$} & \multicolumn{6}{|c|}{ Initial soil moisture content by weight (\%) } \\
\cline { 2 - 11 } & \multicolumn{3}{|c|}{21.4} & \multicolumn{3}{c|}{24.7} & \multicolumn{3}{c|}{27.1} \\
\hline $\mathrm{T}_{\mathrm{s}}(\mathrm{min})$ & 0 & 5 & 10 & 0 & 5 & 10 & 0 & 5 & 10 \\
\hline $\mathrm{T}_{\mathrm{d}}(\mathrm{min})$ & 12.8 & 32.3 & 50.3 & 2.0 & 11.3 & 23.4 & 0.5 & 5.4 & 14.4 \\
\hline $\mathrm{T}_{\text {off }}(\mathrm{min})$ & 40.2 & 45.2 & 50.2 & 28.0 & 33.0 & 38.0 & 18.6 & 23.6 & 28.6 \\
\hline $\mathrm{d}(\mathrm{mm})$ & 88.1 & 106.6 & 121.4 & 66.2 & 80.5 & 94.8 & 49.2 & 62.2 & 77.0 \\
\hline $\bar{Z}(\mathrm{~mm})$ & 107.3 & 123.1 & 136.2 & 77.5 & 90.1 & 103.1 & 51.2 & 63.8 & 78.2 \\
\hline $\mathrm{CV}(\%)$ & 11.6 & 8.8 & 7.2 & 9.8 & 7.3 & 5.6 & 2.3 & 1.5 & 1.0 \\
\hline $\mathrm{DU}(\%)$ & 85.3 & 88.8 & 90.9 & 87.5 & 90.7 & 92.9 & 97.1 & 98.1 & 98.7 \\
\hline $\mathrm{E}_{\mathrm{a}}(\%)$ & 82.1 & 86.6 & 89.1 & 85.4 & 89.3 & 91.9 & 96.2 & 97.5 & 98.4 \\
\hline $\mathrm{I}(\mathrm{d})$ & 17.6 & 21.3 & 24.3 & 13.2 & 16.1 & 19.0 & 10.6 & 13.0 & 15.9 \\
\hline $\mathrm{WU}\left(\mathrm{m}^{3} / \mathrm{ha} / \mathrm{d}\right)$ & 60.9 & 57.8 & 56.1 & 58.5 & 56.0 & 54.4 & 48.5 & 49.0 & 49.3 \\
\hline Yield (Mg/ha) & 25.2 & 27.12 & 28.31 & 29.1 & 30.84 & 32.02 & 33.8 & 34.59 & 34.97 \\
\hline
\end{tabular}

${ }^{*} T_{s}$ is storage phase time, $T_{d}$ is depletion phase time, $T_{\text {off }}$ is water cutoff time, $d$ is schedule depth, $\bar{Z}$ is average infiltrated depth, $C V$ is coefficient of variation, DU is distribution efficiency, $E_{a}$ is application efficiency, I is irrigation interval, and WU is water use.

\subsection{Improving furrow irrigation system by changing storage phase time}

Furrow irrigation was partially wetted by applying $2.2,3.0$, and $4.0 \mathrm{~m}^{3} / \mathrm{h}$ inflow rate. Storage phase time $\left(\mathrm{T}_{\mathrm{s}}\right)$ was placed within inflow rate treatment as shown in Table 4. $\mathrm{T}_{\mathrm{s}}$ improved irrigation design and scheduling management. Both schedule depth (d) and average infiltrated depth $(\bar{Z})$ were increased by the increase of storage time within inflow rate treatment. Average infiltrated width $(w)$ was generally increased by increasing both inflow rate and storage phase time. Coefficient of variation as well as distribution efficiency was improved by increasing $T_{s}$ from 0 to 20 min within inflow rate treatment. Application efficiency $\left(\mathrm{E}_{\mathrm{a}}\right)$ was increased by increasing $\mathrm{T}_{\mathrm{s}}$ and achieved better value as $98.1 \%$ by applying $4 \mathrm{~m}^{3} / \mathrm{h}$ inflow rate plus $20 \mathrm{~min} \mathrm{~T}_{\mathrm{s}}$ with selecting schedule depth (d) equaled to minimum infiltrated depth $\left(\mathrm{Z}_{\mathrm{min}}\right)$. Irrigation interval (I) was increased by increasing $T_{\mathrm{s}}$ due to enhancing infiltrated depth profile along furrow line. Water use per day was decreased by both increasing $T_{\mathrm{s}}$ and 
inflow rate due to improve water uniformity along furrow line. Water saving was achieved as $11.7 \%$ by applying $4 \mathrm{~m}^{3} / \mathrm{h}$ plus $20 \mathrm{~min} \mathrm{~T}_{\mathrm{s}}$ compared to that by $2.2 \mathrm{~m}^{3} / \mathrm{h}$ plus 0 min $\mathrm{T}_{\mathrm{s}}$. On the other hand, it was achieved as $46.4 \%$ by applying $4 \mathrm{~m}^{3} / \mathrm{h}$ plus $20 \mathrm{~min} \mathrm{~T}_{\mathrm{s}}$ in furrow irrigation compared to that by $38.8 \mathrm{~m}^{3} / \mathrm{h}$ plus $20 \mathrm{~min} \mathrm{~T}_{\mathrm{s}}$ in border. Grape yield was increased with increasing inflow rate, with an increase rate between 2.42 to $4.93 \mathrm{Mg} / \mathrm{ha}$. The increase rate was achieved as $2.55 \mathrm{Mg} / \mathrm{ha}$ with increasing $\mathrm{T}_{\mathrm{s}}$ from 0 to $20 \mathrm{~min}$ within $2.2 \mathrm{~m}^{3} / \mathrm{h}$, but it was $1.21 \mathrm{Mg} / \mathrm{ha}$ within $4 \mathrm{~m}^{3} / \mathrm{h}$. A low increase rate and a high yield were occurred for high inflow rate treatments due to improving both water uniformity and application. Grape yield was insignificantly affected by both border and furrow irrigation systems due to supplying adequate water into the rootzone under either low or high inflow rate treatments. As well watered conditions were initial soil moisture content of $24.7 \%$ for border and $25.4 \%$ for furrow.

Furrow irrigation evaluating and scheduling parameters were enhanced by increasing both storage phase time $\left(\mathrm{T}_{\mathrm{s}}\right)$ and soil moisture content as shown in Table 5. Depletion phase and cutoff times were increased by increasing storage phase time within initial moisture treatment. Average of water width (w) was increased by increasing $\mathrm{T}_{\mathrm{s}}$ and decreased by increasing initial soil moisture content. CV and DU were improved within initial soil content by increasing $\mathrm{T}_{\mathrm{s}}$ from 0 to $20 \mathrm{~min}$. Irrigation application efficiency was enhanced from $75.5 \%$ for no $\mathrm{T}_{\mathrm{s}}$ plus $22.7 \%$ moisture treatment to $95.4 \%$ for 20 min $\mathrm{T}_{\mathrm{s}}$ plus $27.2 \%$ moisture treatment. Water saving was achieved as $20.8 \%$ by applying $27.2 \%$ moisture plus 20 min $\mathrm{T}_{\mathrm{s}}$ treatment compared to that by $22.7 \%$ moisture by weight plus 0 $\min \mathrm{T}_{\mathrm{s}}$ treatment. On the other hand, it was achieved as $42.2 \%$ by applying $27.2 \%$ moisture plus $20 \mathrm{~min} \mathrm{~T}_{\mathrm{s}}$ treatment in furrow irrigation compared to that by $27.1 \%$ moisture content by weight plus $10 \mathrm{~min} \mathrm{~T}_{\mathrm{s}}$ treatment in border. Grape yield was increased with increasing both initial soil content and $\mathrm{T}_{\mathrm{s}}$ due to high water uniformity and application. Yield was insignificantly changed for 25.4 and $27.2 \%$ moisture content treatments with $0,10,20$ min $\mathrm{T}_{\mathrm{s}}$ under furrow compared with 24.7 and $27.1 \%$ treatments with 0,5 , and 10 min $\mathrm{T}_{\mathrm{s}}$ under border irrigation. But, it was significantly increased with $21.4 \%$ moisture content under border compared to $22.7 \%$ under furrow irrigation because of grape root system as used to irrigate grape with large distribution by border irrigation and partial distribution by furrow. 
Table 4: Furrow irrigation as improved by three storage phase times within inflow rate.

\begin{tabular}{|c|c|c|c|c|c|c|c|c|c|}
\hline \multirow{2}{*}{$\begin{array}{c}\text { Evaluating } \\
\text { parameters }\end{array}$} & \multicolumn{9}{|c|}{ Inflow rate $\left(\mathrm{m}^{3} / \mathrm{h}\right)$} \\
\cline { 2 - 11 } & \multicolumn{3}{|c|}{2.2} & \multicolumn{3}{c|}{3.0} & \multicolumn{3}{c|}{4.0} \\
\hline $\mathrm{T}_{\mathrm{s}}(\mathrm{min})$ & 0 & 10 & 20 & 0 & 10 & 20 & 0 & 10 & 20 \\
\hline $\mathrm{T}_{\mathrm{d}}(\mathrm{min})$ & 3.0 & 5.0 & 5.2 & 9.2 & 11.4 & 12.3 & 12.0 & 13.3 & 16.0 \\
\hline $\mathrm{T}_{\text {off }}(\mathrm{min})$ & 56.0 & 66.0 & 76.0 & 42.0 & 52.0 & 62.0 & 28.0 & 38.0 & 48.0 \\
\hline $\mathrm{d}(\mathrm{mm})$ & 76.8 & 87.5 & 95.7 & 78.6 & 89.2 & 97.8 & 76.5 & 86.6 & 96.8 \\
\hline $\bar{Z}(\mathrm{~mm})$ & 88.3 & 97.8 & 105.2 & 84.6 & 94.6 & 102.7 & 78.4 & 88.3 & 98.3 \\
\hline $\mathrm{w}(\mathrm{m})$ & 0.388 & 0.412 & 0.441 & 0.414 & 0.458 & 0.503 & 0.397 & 0.478 & 0.542 \\
\hline $\mathrm{CV}(\%)$ & 6.4 & 5.2 & 4.5 & 3.4 & 2.7 & 2.3 & 1.1 & 0.9 & 0.7 \\
\hline $\mathrm{DU}(\%)$ & 91.9 & 93.4 & 94.3 & 95.7 & 96.5 & 97.1 & 98.6 & 98.9 & 99.1 \\
\hline $\mathrm{E}(\%)$ & 86.9 & 89.4 & 90.9 & 92.9 & 94.4 & 95.2 & 97.6 & 98.1 & 98.4 \\
\hline $\mathrm{I}(\mathrm{day})$ & 4.4 & 5.3 & 6.2 & 4.8 & 6.0 & 7.2 & 4.5 & 6.1 & 7.7 \\
\hline $\mathrm{WU}\left(\mathrm{m}^{3} / \mathrm{ha} / \mathrm{d}\right)$ & 31.3 & 30.4 & 29.9 & 29.3 & 28.8 & 28.6 & 27.9 & 27.7 & 27.6 \\
\hline Yield $(\mathrm{Mg} / \mathrm{ha})$ & 29.53 & 30.89 & 31.56 & 32.5 & 33.14 & 33.54 & 34.6 & 34.84 & 35.01 \\
\hline
\end{tabular}

${ }^{*} T_{S}$ is storage phase time, $T_{d}$ is depletion phase time, $T_{\text {off }}$ is water cutoff time, $d$ is schedule depth, $\bar{Z}$ is average infiltrated depth, w is average water width, $\mathrm{CV}$ is coefficient of variation, DU is distribution efficiency, $E_{a}$ is application efficiency, $I$ is irrigation interval, and WU is water use

Table 5: Furrow irrigation as improved by three storage phase times within soil moisture.

\begin{tabular}{|c|c|c|c|c|c|c|c|c|c|}
\hline \multirow{2}{*}{$\begin{array}{c}\text { Evaluating } \\
\text { parameters }\end{array}$} & \multicolumn{7}{|c|}{ Initial soil moisture content by weight (\%) } \\
\cline { 2 - 11 } & \multicolumn{3}{|c|}{22.7} & \multicolumn{3}{|c|}{25.4} & \multicolumn{3}{c|}{27.2} \\
\hline $\mathrm{T}_{\mathrm{S}}(\mathrm{min})$ & 0 & 10 & 20 & 0 & 10 & 20 & 0 & 10 & 20 \\
\hline $\mathrm{T}_{\mathrm{d}}(\mathrm{min})$ & 4.0 & 7.4 & 8.0 & 4.0 & 6.0 & 7.0 & 5.0 & 7.6 & 7.7 \\
\hline $\mathrm{T}_{\text {off }}(\mathrm{min})$ & 106 & 116 & 126 & 53 & 63 & 73 & 37 & 47 & 57 \\
\hline $\mathrm{d}(\mathrm{mm})$ & 87.8 & 98.3 & 106.0 & 75.6 & 86.5 & 93.1 & 71.5 & 83.4 & 91.9 \\
\hline$\overline{\mathrm{Z}}(\mathrm{mm})$ & 116.2 & 124.5 & 130.7 & 87.7 & 97.2 & 103.3 & 77.1 & 88.3 & 96.3 \\
\hline $\mathrm{W}(\mathrm{m})$ & 0.558 & 0.569 & 0.589 & 0.370 & 0.396 & 0.432 & 0.293 & 0.325 & 0.362 \\
\hline $\mathrm{CV}(\%)$ & 11.5 & 10.0 & 9.0 & 6.4 & 5.2 & 4.8 & 3.4 & 2.6 & 2.2 \\
\hline $\mathrm{DU}(\%)$ & 85.3 & 87.3 & 88.5 & 91.8 & 93.4 & 94.0 & 95.7 & 96.7 & 97.3 \\
\hline $\mathrm{E}(\%)$ & 75.5 & 79.0 & 81.1 & 86.3 & 89.0 & 90.1 & 92.8 & 94.5 & 95.4 \\
\hline $\mathrm{I}(\mathrm{day})$ & 7.19 & 8.23 & 9.18 & 4.11 & 5.04 & 5.91 & 3.08 & 3.99 & 4.89 \\
\hline $\mathrm{WU}\left(\mathrm{m}^{3} / \mathrm{ha} / \mathrm{d}\right)$ & 36.0 & 34.4 & 33.5 & 31.5 & 30.6 & 30.2 & 29.3 & 28.8 & 28.5 \\
\hline Yield $(\mathrm{Mg} / \mathrm{ha})$ & 21.53 & 23.1 & 23.07 & 29.45 & 30.68 & 31.20 & 32.41 & 33.21 & 33.62 \\
\hline
\end{tabular}

${ }^{*} T_{s}$ is storage phase time, $T_{d}$ is depletion phase time, $T_{\text {off }}$ is water cutoff time, $d$ is schedule depth, $\bar{Z}$ is average infiltrated depth, $w$ is average water width, $C V$ is coefficient of variation, DU is distribution efficiency, $\mathrm{E}_{\mathrm{a}}$ is application efficiency, $\mathrm{I}$ is irrigation interval, and $\mathrm{WU}$ is water use. 


\section{CONCLUSION}

As practicing surface irrigation in grape farm, border system was used to wholly apply the water into soil surface, but furrow system used to partially apply water when plants were $2.5 \mathrm{~m}$ spaced. Water savings was practically occurred by lessening soil evaporation and deep percolation using furrow irrigation instead of border. Border and furrow irrigation systems were practiced and treated to apply water over three different levels of initial soil moisture content and three inflow rates as related to three storage phase times. A $9.8,12.0$, and $15.5 \mathrm{~m}^{2} / \mathrm{h}$ inflow rate per unit width was applied over soil rootzone with $24.7 \%$ initial moisture content by weight using border irrigation. By using only $9.8 \mathrm{~m}^{2} / \mathrm{h}$ inflow rate, three different initial soil moisture contents as $21.4,24.7$, and $27.1 \%$ by weight were treated by border irrigation. Storage phase time was mainly treated as 0,5 , and $10 \mathrm{~min}$ for both inflow rate and initial moisture treatments using border irrigation. Three different inflow rates $(2.2,3$, and $4 \mathrm{~m}^{3} / \mathrm{h}$ ) were applied by furrow irrigation at $25.1 \%$ soil moisture content by weight. Three different initial soil moisture contents were treated as $22.7,25.4$, and $27.2 \%$ by weight under only $2.2 \mathrm{~m}^{3} / \mathrm{h}$ inflow rate using furrow irrigation. Each treatment of inflow rate or initial soil moisture by furrow irrigation was mainly treated as 0,10 , and $20 \mathrm{~min}$ from storage phase time.

Water advance and recession times were increased by both the increase of inflow rate and the decrease of initial soil moisture content. Empirical power equations were obtained by regression $\left(\mathrm{r}^{2} \geq 0.974\right)$ for water advance and recession times as a function of irrigated field length. Infiltrated irrigation depth that was theoretically defined by the two functions of advance and recession along irrigated field length and an independent function of soil infiltration was highly correlated compared to field infiltrated depth $\left(r^{2} \geq 0.95\right)$. Depletion phase and cutoff times were increased by increasing storage phase time within either inflow rate or initial moisture treatment.

Average infiltrated water depth was increased when both inflow rate and initial soil moisture content were low due to slowly water movement 
along irrigating field. High water distribution efficiency was generally achieved with both high water inflow rate and initial moisture content. The increase of storage phase time improved the water distribution along irrigated field under the condition of schedule depth (d) less than maximum water storage of soil rootzone $\left(\mathrm{d}_{\max }\right)$. Average of water width (w) by furrow irrigation was increased by increasing storage phase time and decreasing both inflow rate and initial soil moisture content.

Application efficiency was improved by increasing initial moisture within storage phase time treatment; furthermore, it was improved by the increase of storage phase time and inflow rate. Irrigation interval depended on how much water to apply per irrigation was increased by increasing the minimum infiltrated water depth. Water saving was improved from 0 to $19 \%$ by increasing both initial moisture content from 21.4 to $27.1 \%$ and storage phase time from 0 to 10 min using border irrigation. Water saving was achieved as $46.4 \%$ by applying $4 \mathrm{~m}^{3} / \mathrm{h}$ plus 20 min storage phase time $\left(\mathrm{T}_{\mathrm{s}}\right)$ in furrow irrigation compared to that by $15.5 \mathrm{~m}^{2} / \mathrm{h}$ plus $10 \mathrm{~min} \mathrm{~T}_{\mathrm{s}}$ in border. It was achieved as $42.2 \%$ by applying $27.2 \%$ moisture content plus 20 min $\mathrm{T}_{\mathrm{s}}$ treatment in furrow irrigation compared to that by $27.1 \%$ soil moisture content plus $10 \mathrm{~min}_{\mathrm{s}}$ treatment in border.

Grape yield was generally increased by improving water uniformity and application unless water depletion was not more than 50\%. Consequently, yield was increased with increasing inflow rate, initial soil moisture, and storage phase time. Yield was insignificantly affected by both border and furrow irrigation systems in well-watered condition for the parallel inflow rate with storage phase treatments. But, yield was significantly increased by border compared with furrow irrigation when soil was initialized less than $24 \%$ by weight due to reducing grape root system under furrow.

\section{REFERENCES}

Alazba, A.A. (1999). Dimensionless advance curves for infiltration families. Agricultural water management, 41, 115-131.

Amer, K.H. (2007). Surface irrigation evaluation based on analytical interrelation among water infiltration, advance, and recession. 
Proceeding of Irrigation Association, 9-11 Dec in San Diego, CA: 433445.

Bishop, A.A. (1962). Relation of intake rate to length of run in surface irrigation. Trans. of the ASCE 127 part III.

Blair, A.W. and E.T. Smerdon (1988). Unimodal surface irrigation efficiency. J. of Irrig. And Drain. Div., ASCE, 114(1), 156-167.

Cahoon, J.E., P.A. Mandel, and D. E. Eisenhauer (1995). Management recommendations for sloping blocked-end furrow irrigation. Applied Engineering in Agriculture, ASAE, 11(4), 527-533.

DeTar, W.R. (1989). Infiltration functions from furrow stream advance. J. Irrigation Drainage Eng. ASCE 115 (4), 722-730.

Dholakia, M., R. Misra, and M.S. Zaman (1998). Simulation of border irrigation system using explicit MacCormack finite difference method. Agric. Water Manage., 36, 181-200.

Elliot, R.L. and W.R. Walker (1982). Field evaluation of furrow infiltration and advance functions. Trans. ASAE 15(2), 369-400.

Green, R.E. and C.W. Guernsey (1984). Soil-water relations and physical properties of irrigated soils in the Kula area, Island of Maui, Hawaii. Res. Bull., 173, Hawaii University.

Hartley, D.M. (1992). Interpretation of Kostiakow infiltration parameters for borders. J. Irrrig. Drain. Eng. 118(1), 156-165).

Holizapfel, E.A., Marino, M.A., Morales, J.C., 1984. Comparison and selection of furrow irrigation models. Agricultural water management, 9, 105-125.

Hume, I.H. (1993) Determination of infiltration characteristics by volume balance for border check irrigation. Agric. Water Manage., 23, 23-39.

Foroud, N., E.S. George, and T. Entz (1996). Determination of infiltration rate from border irrigation advance and recession trajectories. Agricultural Water Management 30, 133-142.

Kostiakov, A.N (1932). On the dynamics of coefficient of waterpercolation in soils and the necessity of studying it from a dynamic point of view for purposes of amelioratium. Trans. Com. Int. Soc. Soil Sci. 6, 267-272. 
Maheshwari, B.L., A.K. Turner, T.A.McMahon, and B.J Campbell (1988). An optimization technique for estimating infiltration characteristics in border irrigation. Agric. Water Manage. 13, 13-24.

Michael, A.M. and A.C. Pandya (1971). Hydraulic resistance relationship in irrigation borders. J. Agric. Engng. Res. 13(1), 72-80.

Rodriguez, J.A. (2003). Estimation of advance and infiltration equations in furrow irrigation for untested discharges. Agricultural Water Management 60, 227-239.

Scaloppi, E.J., G.P. Merkley, and L.S. Willardson (1995). Intake parameters from advance and wetting phases of surface irrigation. J. Irrigation Drainage Eng. ASCE 121 (1), 57-70.

Smerdon, E.T., A.W. Blair, and D.L. Reddell (1988). Infiltration from irrigation advance data. I. Theory. J. Irrigation Drainage Eng. ASCE 114 (1), 4-17.

Valiantzas, J.D., S. Aggelides, and A. Sassalou (2000). Furrow infiltration estimation from time to a single advance point. Agricultural Water Management 52, 17-32.

Vaziri, C.M. and I. P. Wu (1972). Volume balance analysis to determine water infiltration and efficiency in Hawaiian sugarcane furrows. Hawaiian Sugar Planters Association 58(20), 283-292.

Walker, W.R. and G.V. Skogerboe (1987). Surface irrigation: Theory and Practice. Prentice-Hall, Englewood Cliffs, NJ 07632, 386 pp.

Wu, I.P. (1971). Overland flow hydrograph analysis to determine infiltration function. Trans. of the ASAE. 14(2): 294-300.

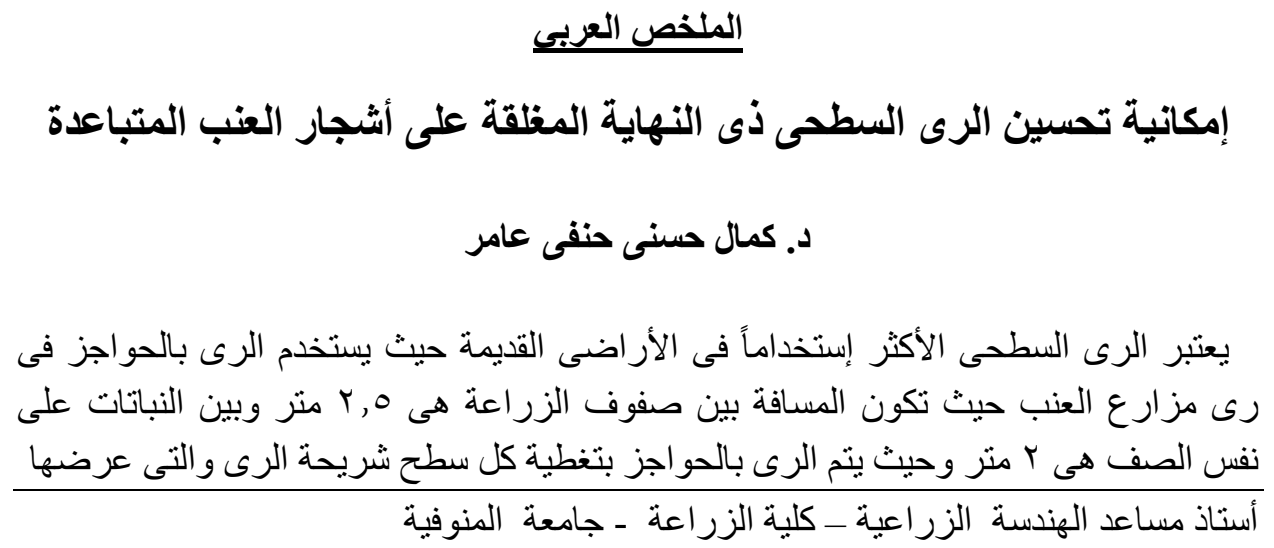


الم r,o متر , وبما أن تغطية نبات العنب نكون تغطية غير كاملة مما تسبب فقداً كبيراً من المياه

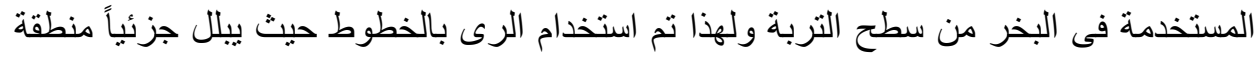

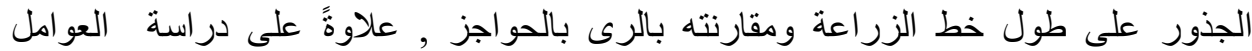

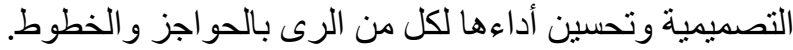

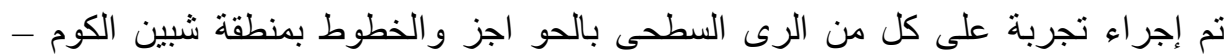

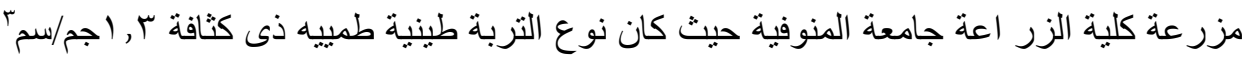

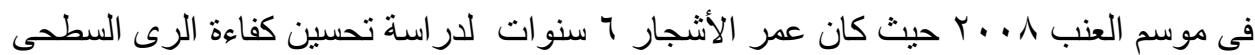

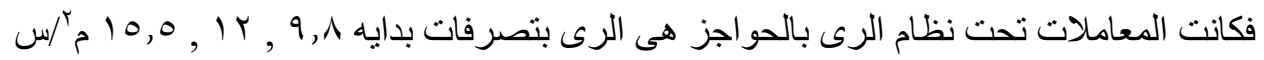

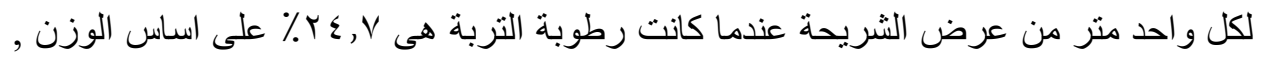

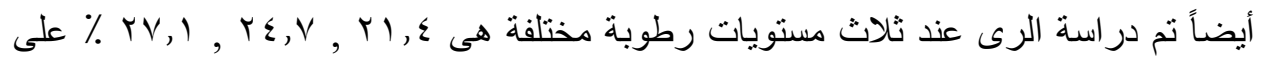

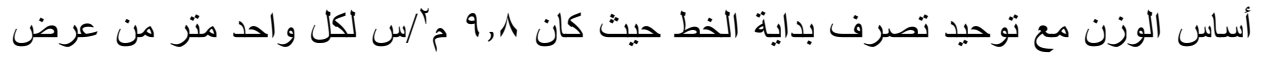

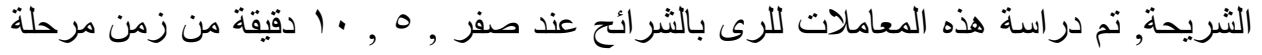

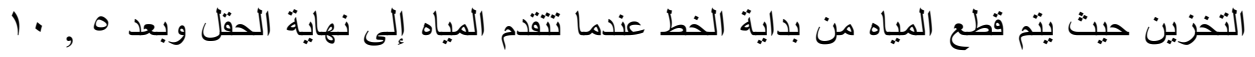

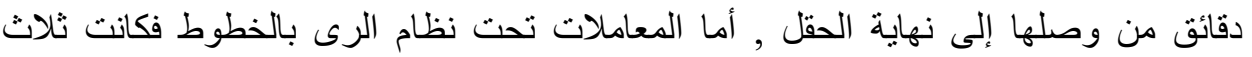

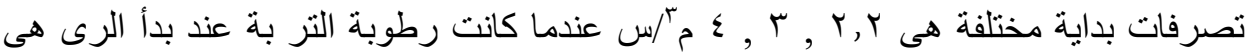

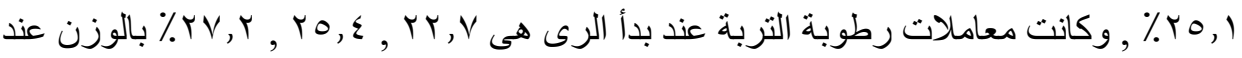

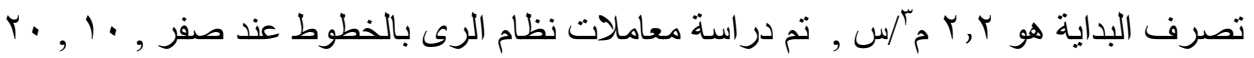
دقيقة من وقت مرحلة التخزين.

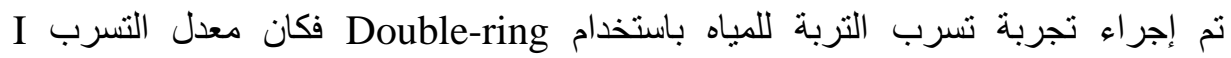

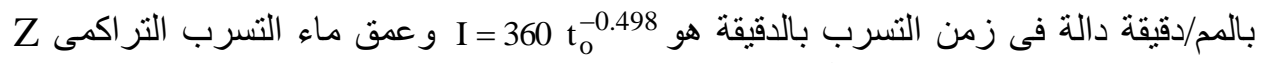

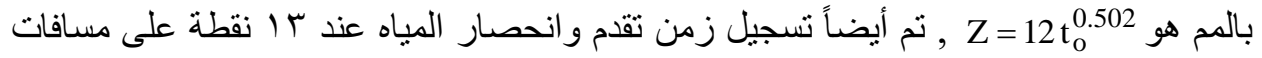
ه متر على طول خط أو شريحة الرى ثم إيجاد دالتا الإنحصار و التقدم لكل المعاملات التهات السابق

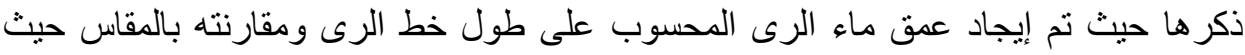

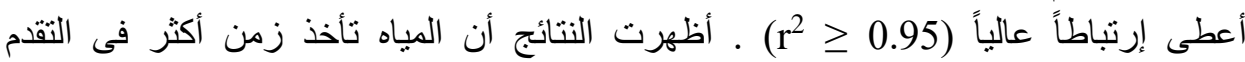

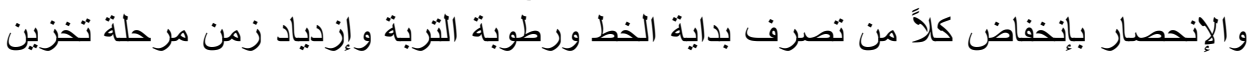

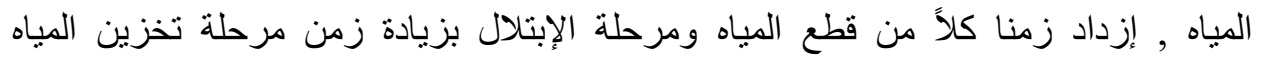
لمعاملات الرى بالثر ائح أو الخطوط.

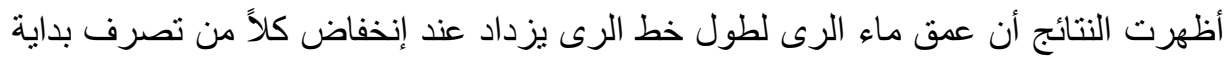

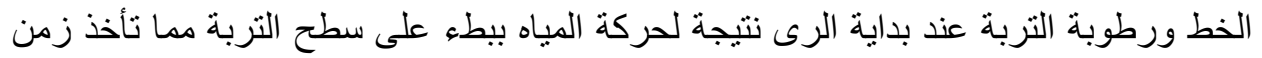

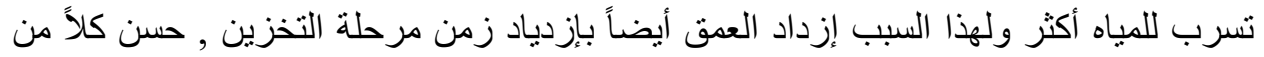

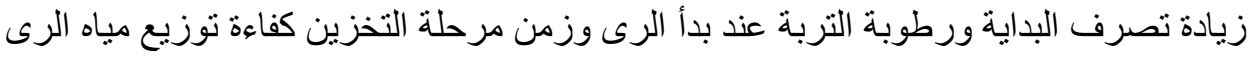

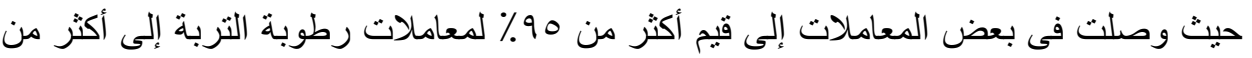

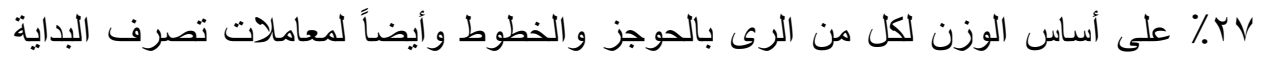

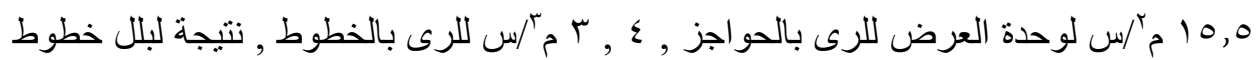


الرى جزئياً فقد نأثر منوسط عرض بلل الخط حيث إزداد بزيادة زمن مرحلة التخزين و إزداد

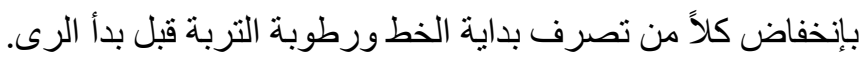

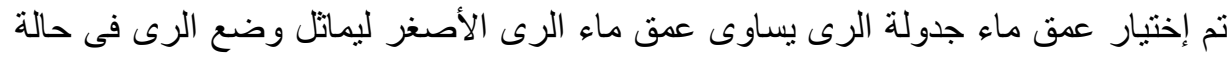

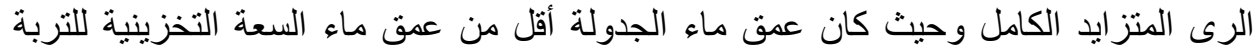

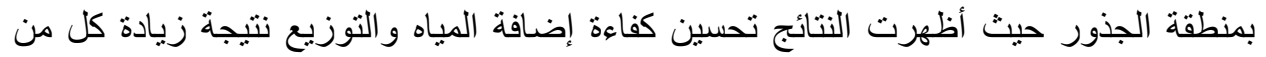
زمن مرحلة التخزين وتصرف بداية الخط ورطوبة التربة , تباعدت الفترة بين الريات بزية بلتيادة

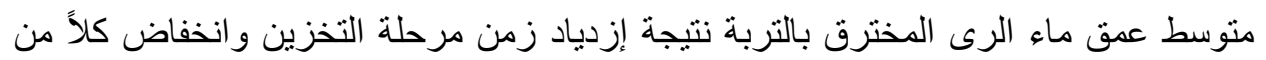

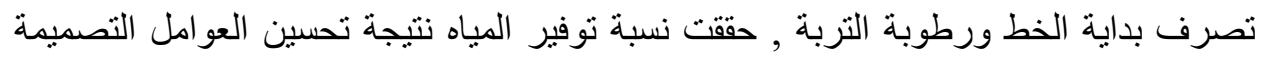

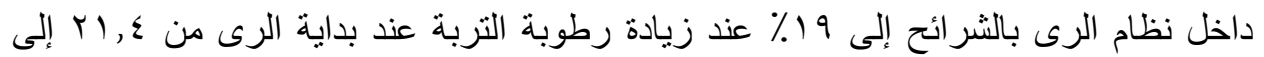

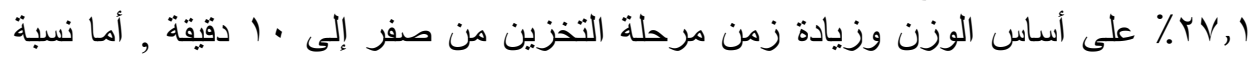

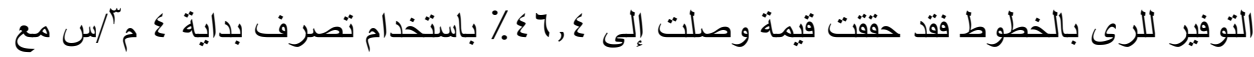

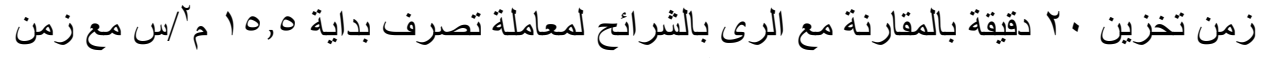

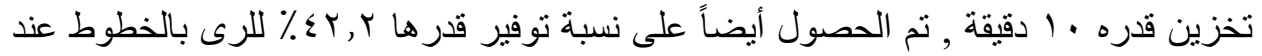

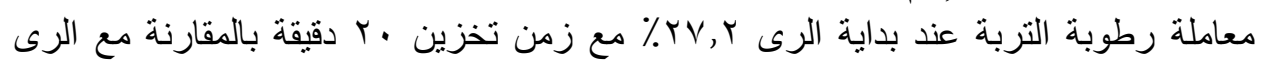

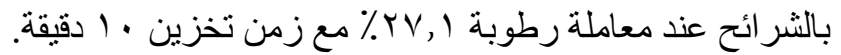

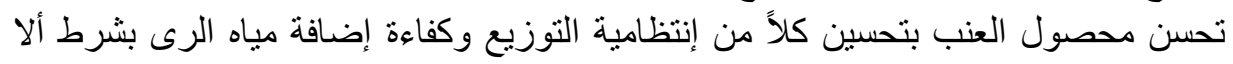

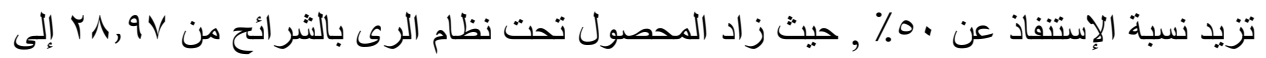

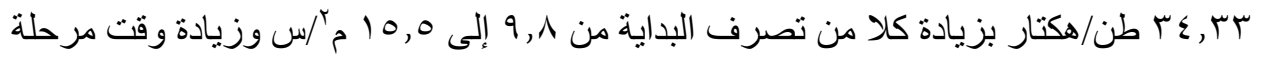

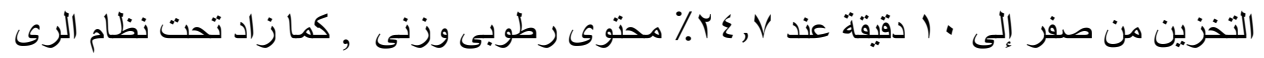

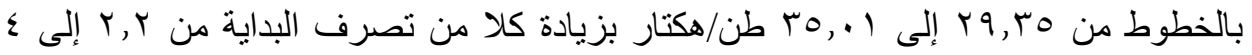

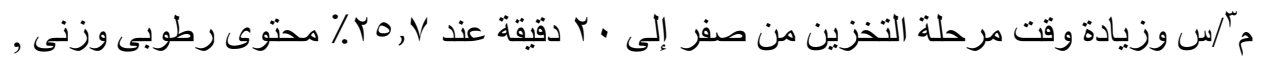

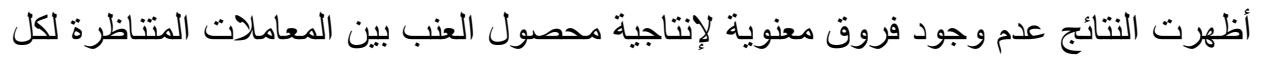

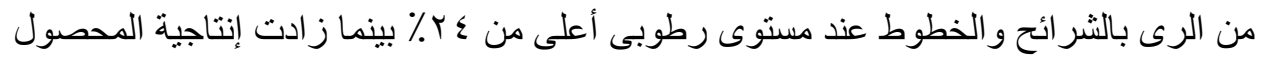

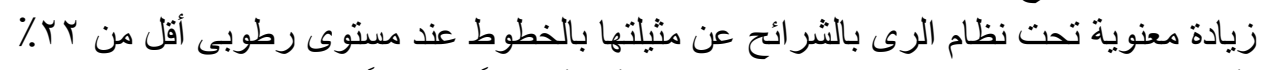

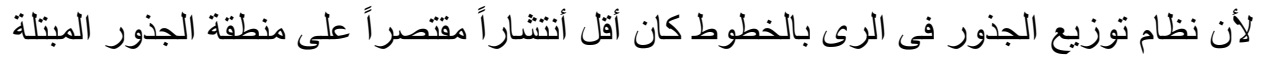
جزئياً بالمياه. 